University of Nebraska - Lincoln

DigitalCommons@University of Nebraska - Lincoln

\title{
Passive Aerobic Treatment of Net-Alkaline, Iron-Laden Drainage from a Flooded Underground Anthracite Mine, Pennsylvania, USA
}

Charles A. Cravotta III

US Geological Survey, PA Water Science Center, 215 Limekiln Rd, New Cumberland, PA, USA, cravotta@usgs.gov

Follow this and additional works at: https://digitalcommons.unl.edu/usgsstaffpub

Part of the Earth Sciences Commons

Cravotta III, Charles A., "Passive Aerobic Treatment of Net-Alkaline, Iron-Laden Drainage from a Flooded Underground Anthracite Mine, Pennsylvania, USA" (2007). USGS Staff -- Published Research. 275.

https://digitalcommons.unl.edu/usgsstaffpub/275

This Article is brought to you for free and open access by the US Geological Survey at DigitalCommons@University of Nebraska - Lincoln. It has been accepted for inclusion in USGS Staff -- Published Research by an authorized administrator of DigitalCommons@University of Nebraska - Lincoln. 


\title{
Passive aerobic treatment of net-alkaline, iron-laden drainage from a flooded underground anthracite mine, Pennsylvania, USA
}

\author{
Charles A. Cravotta III
}

Received: 3 April 2007/Accepted: 1 May 2007/Published online: 18 August 2007

(C) Springer-Verlag 2007

\begin{abstract}
This report evaluates the results of a continuous 4.5-day laboratory aeration experiment and the first year of passive, aerobic treatment of abandoned mine drainage (AMD) from a typical flooded underground anthracite mine in eastern Pennsylvania, USA. During 1991-2006, the AMD source, locally known as the Otto Discharge, had flows from 20 to $270 \mathrm{~L} / \mathrm{s}$ (median $92 \mathrm{~L} / \mathrm{s}$ ) and water quality that was consistently suboxic (median $0.9 \mathrm{mg} / \mathrm{L} \mathrm{O}_{2}$ ) and circumneutral $(\mathrm{pH} \approx 6.0$; net alkalinity $>10$ ) with moderate concentrations of dissolved iron and manganese and low concentrations of dissolved aluminum (medians of 11, 2.2, and $<0.2 \mathrm{mg} / \mathrm{L}$, respectively). In 2001, the laboratory aeration experiment demonstrated rapid oxidation of ferrous iron $\left(\mathrm{Fe}^{2+}\right)$ without supplemental alkalinity; the initial $\mathrm{Fe}^{2+}$ concentration of $16.4 \mathrm{mg} / \mathrm{L}$ decreased to less than $0.5 \mathrm{mg} / \mathrm{L}$ within $24 \mathrm{~h}$; $\mathrm{pH}$ values increased rapidly from 5.8 to 7.2, ultimately attaining a steady-state value of 7.5 . The increased $\mathrm{pH}$ coincided with a rapid decrease in the partial pressure of carbon dioxide $\left(\mathrm{PCO}_{2}\right)$ from an initial value of $10^{-1.1}$ atm to a steady-state value of $10^{-3.1}$ atm. From these results, a staged aerobic treatment system was conceptualized consisting of a $2 \mathrm{~m}$ deep pond with innovative aeration and recirculation to promote rapid oxidation of $\mathrm{Fe}^{2+}$, two $0.3 \mathrm{~m}$ deep wetlands to facilitate iron solids removal, and a supplemental oxic limestone drain for dissolved manganese and trace-metal removal. The system was constructed, but without the aeration mechanism, and began operation in
\end{abstract}

Electronic supplementary material The online version of this article (doi:10.1007/s10230-007-0002-8) contains supplementary material, which is available to authorized users.

C. A. Cravotta III ( $₫)$

US Geological Survey, PA Water Science Center,

215 Limekiln Rd, New Cumberland, PA, USA

e-mail: cravotta@usgs.gov
June 2005. During the first 12 months of operation, estimated detention times in the treatment system ranged from 9 to $38 \mathrm{~h}$. However, in contrast with $80-100 \%$ removal of $\mathrm{Fe}^{2+}$ over similar elapsed times during the laboratory aeration experiment, the treatment system typically removed less than $35 \%$ of the influent $\mathrm{Fe}^{2+}$. Although concentrations of dissolved $\mathrm{CO}_{2}$ decreased progressively within the treatment system, the $\mathrm{PCO}_{2}$ values for treated effluent remained elevated $\left(10^{-2.4}\right.$ to $10^{-1.7}$ atm). The elevated $\mathrm{PCO}_{2}$ maintained the $\mathrm{pH}$ within the system at values less than 7 and hence slowed the rate of $\mathrm{Fe}^{2+}$ oxidation compared to the aeration experiment. Kinetic models of $\mathrm{Fe}^{2+}$ oxidation that consider effects of $\mathrm{pH}$ and dissolved $\mathrm{O}_{2}$ were incorporated in the geochemical computer program PHREEQC to evaluate the effects of detention time, $\mathrm{pH}$, and other variables on $\mathrm{Fe}^{2+}$ oxidation and removal rates. These models and the laboratory aeration experiment indicate that performance of this and other aerobic wetlands for treatment of net-alkaline AMD could be improved by aggressive, continuous aeration in the initial stage to decrease $\mathrm{PCO}_{2}$, increase $\mathrm{pH}$, and accelerate $\mathrm{Fe}^{2+}$ oxidation.

Keywords Aerobic wetlands - Iron oxidation · Carbon dioxide exsolution $\cdot$ Kinetics modeling

\section{Introduction}

Problem

Drainage from abandoned coalmines degrades more than $8,000 \mathrm{~km}$ of streams in the northern Appalachian region, USA; many of these streams are fishless or contain few fish (U.S. Environmental Protection Agency 2006; Herlihy et al. 1990). Although acidic $\mathrm{pH}(<4.5)$ and elevated 
concentrations of dissolved sulfate, iron, and other metals are common characteristics of abandoned mine drainage (AMD), a substantial percentage of the AMD in the Northern Appalachian Region is iron-laden but not acidic (Cravotta et al. 1999; Hyman and Watzlaf 1997; Kirby and Cravotta 2005a; Rose and Cravotta 1998). For example, in $1999,30 \%$ of 140 sampled AMD sources in the Bituminous and Anthracite Coalfields of Pennsylvania had concentrations of dissolved iron greater than the $7 \mathrm{mg} / \mathrm{L}$ criteria for effluent from active mines in Pennsylvania (Commonwealth of Pennsylvania 2002) and had net-alkaline water quality, with near-neutral $\mathrm{pH}$ (6.0-7.5) (Cravotta 2007; Kirby and Cravotta 2005b). Despite their net-alkaline water quality, the dissolved iron tends to precipitate downstream from the AMD sources, forming ochreous encrustations that degrade the aquatic habitat (Earle and Callaghan 1998; Williams et al. 2002; Winland et al. 1991). Various alternatives for treatment to remove the dissolved iron and associated metals from AMD before it discharges to streams could be appropriate depending on the volume of the mine discharge, its alkalinity and acidity balance, and the available resources for construction and maintenance of a treatment system (Hedin et al. 1994; Skousen et al. 1998). Information on the hydrologic variability and the site characteristics is needed by waterresource managers to identify effective remedial strategies for the AMD.

\section{Background}

Current guidelines for passive treatment of coalmine drainage (Skousen et al. 1998; Watzlaf et al. 2004) were largely developed by the former U.S. Bureau of Mines (Hedin et al. 1994) on the basis of systems that were constructed for treatment of AMD in the Bituminous Coalfield of Pennsylvania and West Virginia. These guidelines indicate different treatment strategies for net-alkaline and net-acidic water quality. For AMD that has net acidity (alkalinity < acidity; hot peroxide acidity $>0$ ), treatment systems that promote alkalinity production are appropriate. The alkalinity can be produced by limestone dissolution and, in some cases, sulfate reduction (e.g., Hedin et al. 1994; Langmuir 1997). Net-alkaline AMD does not require supplemental alkalinity and can be routed directly to an oxidation pond(s) and/or aerobic wetland(s) where dissolved iron is oxidized and precipitated from solution. Typically, to determine the areal extent of an aerobic system, the average iron-loading rate of the AMD source expressed in grams per day (g/day) is divided by an assumed iron-removal rate of $20 \mathrm{~g} / \mathrm{m}^{2} /$ day, based on the work of Hedin et al. (1994). However, this areal-removal rate may not be applicable for AMD that differs in character from typical Bituminous Coalfield AMD. Studies at wetlands receiving AMD have indicated that the prescribed iron-removal rate of $20 \mathrm{~g} / \mathrm{m}^{2} /$ day can underestimate the area needed for effective treatment, particularly as $\mathrm{pH}$ and/ or concentrations of iron decrease (Kirby et al. 1999; Tarutis et al. 1999; Watzlaf et al. 2004). Generally, flow rates are higher and concentrations of acidity, sulfate, and iron are lower for similar $\mathrm{pH}$ in the Anthracite Coalfield compared to the Bituminous Coalfield of Pennsylvania (Cravotta 2007).

The oxidation rate of iron in aqueous systems is complex and tends to increase with water temperature, $\mathrm{pH}$, concentration of dissolved oxygen, concentrations of dissolved and suspended iron, and bacterial activity (Dempsey et al. 2001; Kirby et al. 1999; Stumm and Lee 1961; Stumm and Morgan 1996; Watzlaf et al. 2001 2004; Williamson et al. 1992). In the presence of dissolved oxygen $\left(\mathrm{O}_{2}\right)$, concentrations of dissolved iron tend to decrease because of oxidation and hydrolysis reactions that lead to the formation of various ferric-hydroxide and hydroxysulfate solids, hereinafter denoted $\mathrm{Fe}(\mathrm{OH})_{3}$ :

$\mathrm{Fe}^{2+}+0.25 \mathrm{O}_{2}+2.5 \mathrm{H}_{2} \mathrm{O} \rightarrow \mathrm{Fe}(\mathrm{OH})_{3}(\mathrm{~s})+2 \mathrm{H}^{+}$

Generally, the ferrous iron $\left(\mathrm{Fe}^{2+}\right)$ oxidation step is ratelimiting; ferric iron $\left(\mathrm{Fe}^{3+}\right)$ hydrolysis and precipitation of $\mathrm{Fe}(\mathrm{OH})_{3}$ are nearly instantaneous (Singer and Stumm 1970; Stumm and Morgan 1996). Despite initial pH values that can be near neutral, some AMD containing dissolved iron can have acidic $\mathrm{pH}(<4.5)$ after complete oxidation because of the release of protons $\left(\mathrm{H}^{+}\right)$associated with iron hydrolysis. As equation 1 proceeds to completion, the $\mathrm{pH}$ will decrease unless buffered by excess alkalinity, indicated by positive values for net alkalinity or negative values for hot peroxide acidity (Kirby and Cravotta 2005a, b).

The $\mathrm{pH}$, alkalinity, and associated properties of AMD also can change as a water sample equilibrates to atmospheric conditions because of the exsolution of dissolved carbon dioxide $\left(\mathrm{CO}_{2}\right)$. Ground water and coalmine drainage commonly contain elevated concentrations of dissolved $\mathrm{CO}_{2}$, resulting in partial pressure of $\mathrm{CO}_{2}\left(\mathrm{PCO}_{2}\right)$ of $10^{-1.5}$ to $10^{-0.5}$ atm in the vadose zone (Langmuir 1997; Rose and Cravotta 1998). When exposed at the surface, excess $\mathrm{CO}_{2}$ will exsolve until dissolved $\mathrm{CO}_{2}$ concentrations equilibrate with atmospheric $\mathrm{PCO}_{2}$ of approximately $10^{-3.5}$ atm. To explain effects on $\mathrm{pH}$ and alkalinity, the $\mathrm{CO}_{2}$ exsolution process may be described as:

$\mathrm{HCO}_{3}^{-} \leftrightarrow \mathrm{CO}_{2}(\mathrm{~g})+\mathrm{OH}^{-}$,

where equation 2 goes to the right. The $\mathrm{pH}$ will increase as $\mathrm{CO}_{2}$ exsolves. Exsolution of $\mathrm{CO}_{2}$ can be promoted by aeration within a stream or aggressive air sparging in a treatment system (Jageman et al. 1988). Unless 
accompanied by the precipitation of $\mathrm{Fe}(\mathrm{OH})_{3}, \mathrm{CaCO}_{3}$, or other solids, the alkalinity will not be affected by equation 2 because bicarbonate $\left(\mathrm{HCO}_{3}^{-}\right)$and hydroxyl $\left(\mathrm{OH}^{-}\right)$ions have equivalent capacity to neutralize acid; that is, they have equivalent alkalinity. On the other hand, if $\mathrm{Fe}(\mathrm{OH})_{3}$ precipitates in accordance with Eq. 1, alkalinity will decrease and the $\mathrm{pH}$ also could decrease, but not necessarily. For solutions containing dissolved iron and excess $\mathrm{CO}_{2}$, the $\mathrm{pH}$ could increase or decrease depending on the concentrations of these constituents and the relative rates of reactions (1) and (2).

Wetlands designed for removal of iron may be inadequate for the removal of dissolved manganese and various trace metals. Alkaline $\mathrm{pH}$ values may be necessary for attenuation of these metals. At neutral to alkaline $\mathrm{pH}$, iron and manganese oxides can be effective sorbents of dissolved manganese, copper, cobalt, nickel, zinc, cadmium, and other potentially toxic trace metals (Kooner 1993; McKenzie 1980). Such metals have been identified with ochreous precipitates at AMD sites (Kairies et al. 2005; Webster et al. 1998; Williams et al. 2002; Winland et al. 1991). Adsorption of the cations by the hydrous iron and manganese oxides generally is interpreted to be the primary mechanism for removal of the metals. For example, cobalt, nickel, and zinc in AMD were attenuated under oxidizing conditions within a buried limestone bed, but only after iron and manganese oxides precipitated near the inflow had migrated downgradient where the $\mathrm{pH}$ was near neutral (Cravotta and Trahan 1999; Cravotta and Watzlaf 2002).

Although elevated temperatures can produce faster rates of iron oxidation and more effective treatment in AMD wetlands (Dempsey et al. 2001; Kirby et al. 1999), the prolonged exposure of AMD to ambient air temperatures or sunshine can produce temperature extremes that are not suitable for fish and other aquatic organisms. Directing effluent from a shallow wetland through a trench filled with limestone or other rock fragments can moderate the water temperature. Ideally, the treated AMD effluent quality and temperature would sustain fish and other aquatic life.

\section{Purpose and Scope}

This report presents information that could be useful to water-resource managers to assess remedial strategies for net-alkaline, iron-laden AMD. The report describes field, laboratory, and computational methods and water-quality data collected by the U.S. Geological Survey (USGS) during 2001-2006 for the evaluation of passive-treatment strategies and performance results at a flooded underground anthracite mine in eastern Pennsylvania that is locally known as the Otto Discharge. A laboratory aeration experiment conducted in December 2001 is presented as the basis for the design of aerobic wetlands for treatment of the Otto Discharge. The performance of the treatment system is evaluated on the basis of water-quality data collected monthly during June 2005 to June 2006 at the inflow, outflow, and intermediate points within the treatment system and on the receiving stream above and below the discharge. Lastly, geochemical models of iron oxidation are used to evaluate detention time and chemical factors affecting iron oxidation and removal.

\section{Description of Study Area}

The Otto Colliery Discharge (Otto Discharge; lat. $40^{\circ} 39^{\prime} 58^{\prime \prime} \mathrm{N}$, long. $76^{\circ} 19^{\prime} 14^{\prime \prime}$ W) near Branchdale, Schuylkill County, is one of the largest sources of AMD in the Schuylkill River Basin in eastern Pennsylvania (Fig. 1). The upper Schuylkill River Basin originates within the Southern Anthracite Coalfield of the Appalachian Mountain Section of the Ridge and Valley Physiographic Province, where it is underlain by strongly folded and faulted sandstone, shale, siltstone, conglomerate, and coal of the Llewellyn and Pottsville Formations (Wood et al. 1986; Eggleston et al. 1999; Way 1999). Since the late 1800 s, a total of 38 mapped coalbeds with average thicknesses from 0.3 to $2.5 \mathrm{~m}$ have been mined to depths exceeding 1,000 $\mathrm{m}$ in the Southern Anthracite Coalfield (Wood et al. 1986). Although several surface and underground anthracite mines presently (2007) are active, most mines in the upper Schuylkill River Basin were abandoned before 1960 and are flooded. Fresh surface and ground water that enters the mines acquires acidity, sulfate, iron, and other metals and eventually discharges as AMD from mine shafts, tunnels, and topographically low points (Growitz et al. 1985; Robert Kimball and Associates 2000; Pennsylvania Department of Environmental Protection 2003; Wood 1996). The metal-laden AMD contributes substantially to base flow but degrades stream-water quality and aquatic habitat of the Schuylkill River and its upper tributaries. Consequently, the West Branch and upper Schuylkill River are on the U.S. Environmental Protection Agency (USEPA) 303(d) list of impaired waters in Pennsylvania (Pennsylvania Department of Environmental Protection 2003, 2004).

The Otto Mine operated from the early 1800s to 1934 and encompassed an area of approximately $20 \mathrm{~km}^{2}$ (Guy Mace, White Pine Coal Company, oral communication, 2006). During the life of the mine, thousands of metric tons of anthracite were extracted from 13 named coal beds (Rabbit Hole through Buck Mountain) to a maximum depth of $60 \mathrm{~m}$ below sea level (Eggleston et al. 1999; Guy Mace, White Pine Coal Co., oral communication, 2006). After the Otto Mine closed, the underground voids flooded and the 


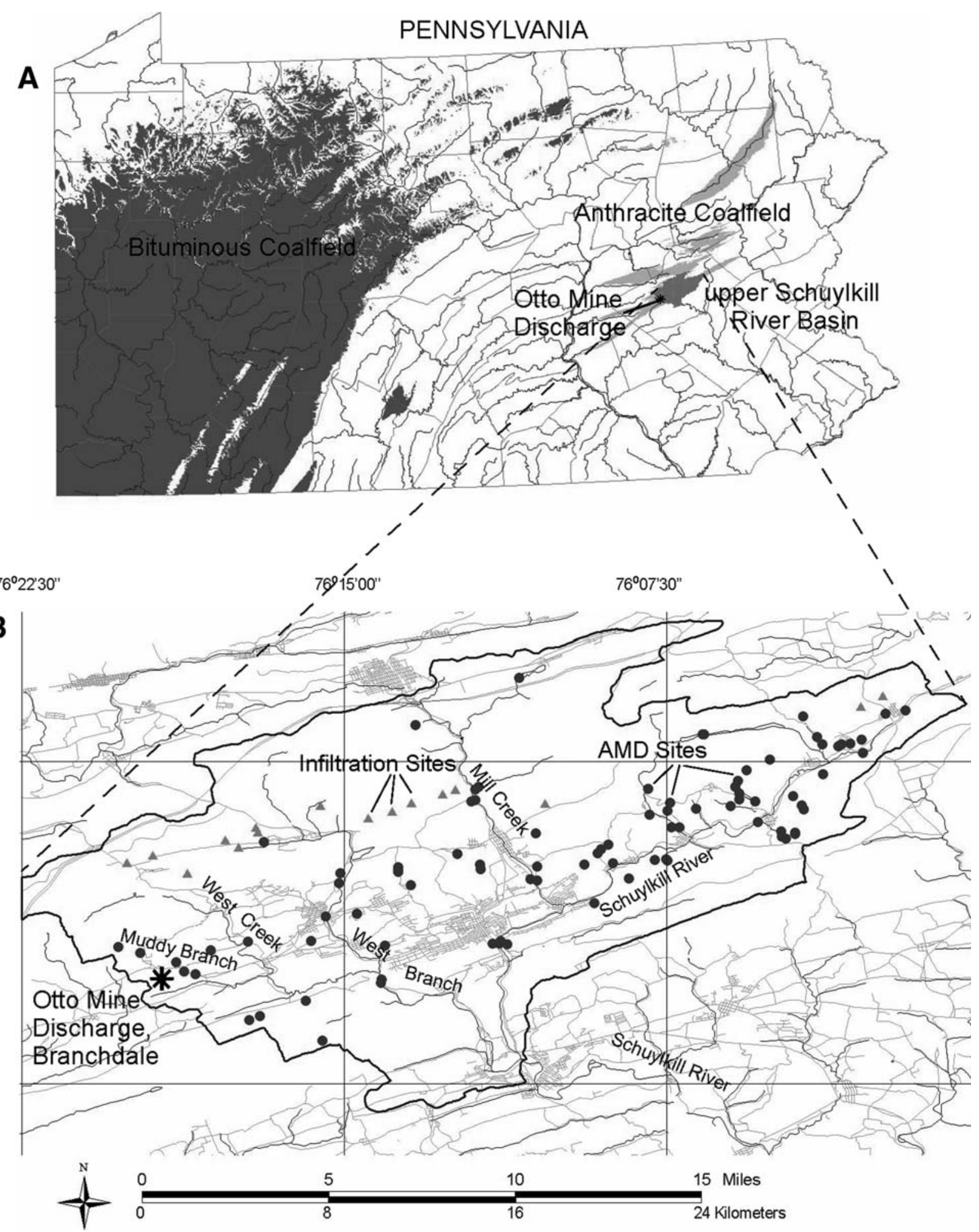

Fig. 1 Maps showing location of the Otto Discharge. a Bituminous and Anthracite Coalfields of Pennsylvania; b Abandoned mine drainage $(A M D)$ in the upper Schuylkill River Basin, Schuylkill present discharge developed from a production tunnel and associated shaft. The untreated AMD exits the tunnel at an elevation of $250 \mathrm{~m}$ above the National Geodetic Vertical
County, Pa. Coalfield boundaries based on distribution of Pennsylvanian bedrock (Berg et al. 1980). Map of upper Schuylkill River Basin adapted from L. Robert Kimball and Associates, Inc. (2000)

Datum of 1929 (NGVD 29) and flows down a $470 \mathrm{~m}$ long, rock-inlaid ditch to elevation $238 \mathrm{~m}$ above NGVD 29 at Muddy Branch (Fig. 1). At their confluence, the Otto 
Discharge contributes the majority of streamflow in Muddy Branch, which flows eastward to West Creek and eventually the West Branch of the Schuylkill River. Below their confluence, the water and streambed of Muddy Branch are a rusty orange-brown, owing to loading of iron and other metals from the Otto Discharge. Despite the metals loading, the Pennsylvania Fish Commission (Chikotas and Kaufman 2002) documented high densities of native brook trout (Salvelinus fontinalis) in Muddy Branch downstream from the Otto Discharge. The brook trout benefit from sustained inflows of cold, near-neutral water from the Otto Discharge; however, populations of aquatic insects and other fish species tend to be limited because of iron-oxide deposits in the streambed (e.g., Earle and Callaghan 1998).

Data collected by the USGS from 1991 to 2006 (this paper; Williams et al. 2002; Wood 1996) indicate that the Otto Discharge ranges widely in flow (20-270 L/s; median $92 \mathrm{~L} / \mathrm{s})$ but is consistently net alkaline $(\mathrm{pH}=5.7-6.1$; alkalinity $=34-70 \mathrm{mg} / \mathrm{L} \quad \mathrm{CaCO}_{3}$ ), anoxic to suboxic $\left(<0.1-2.2 \mathrm{mg} / \mathrm{L} \quad \mathrm{O}_{2}\right)$, and contaminated with sulfate $\left(\mathrm{SO}_{4}=190-370 \mathrm{mg} / \mathrm{L}\right)$, iron $(\mathrm{Fe}=3-16 \mathrm{mg} / \mathrm{L})$, manganese $(\mathrm{Mn}=2-3 \mathrm{mg} / \mathrm{L})$, aluminum $(\mathrm{Al}=0.1-1.3 \mathrm{mg} / \mathrm{L})$, and other dissolved metals. On the basis of its net-alkaline water quality and flow characteristics, the effluent from the Otto Discharge could be treated with a passive aerobic wetland system for removal of iron and other metals (e.g., Hedin et al. 1994).

\section{Treatment System Design and Construction}

A passive aerobic treatment system was conceptualized to facilitate the removal of iron, manganese, and other metals from the Otto Discharge while maintaining the sustained flows of oxygenated, cold water required by native brook trout in downstream reaches of Muddy Branch. The conceptual treatment system would divert the existing discharge with a low-head dam; promote aeration with an in-line hydraulic device; detain the aerated water within an oxidation pond; promote deposition of iron-hydroxide precipitates that form as a consequence of aeration within the oxidation pond and two constructed, aerobic wetland cells; and remove manganese and trace metals in a flushable, oxic limestone drain that would add alkalinity and mitigate temperature fluctuations. The proposed in-line hydraulic aeration would take advantage of gravity and use venturi nozzles near the pipe outlet to draw air into the pipe (e.g., Ackman and Kleinmann 1985), hence, supersaturating the influent with atmospheric $\mathrm{O}_{2}$ before discharging to the first treatment cell. The aerated influent would be injected near the bottom of the oxidation pond to promote the circulation of the water and $\mathrm{Fe}(\mathrm{OH})_{3}$ particles. The circulation of $\mathrm{Fe}(\mathrm{OH})_{3}$ particles could facilitate particle coagulation and settling, plus oxidation rates could be increased by sorption of $\mathrm{Fe}^{2+}$ and catalysis on $\mathrm{Fe}(\mathrm{OH})_{3}$ surfaces at near-neutral $\mathrm{pH}$. The abiotic oxidation of sorbed $\mathrm{Fe}^{2+}$ (heterogeneous oxidation) generally is faster than the oxidation of dissolved $\mathrm{Fe}^{2+}$ (homogeneous oxidation) (Dempsey et al. 2001; Dietz and Dempsey 2002; Kirby et al. 1999; Stumm and Sulzberger 1992; Tamura et al. 1976). Enhancing iron removal by heterogeneous oxidation could improve treatment efficiency and produce a denser sludge.

Landowner consent was obtained, detailed engineering was completed, construction permits were approved, and, in June 2005, construction of the treatment system was completed by private-sector companies on behalf of the Schuylkill Headwaters Association, Inc. The "as-built" system incorporated most basic features of the conceptual design. However, to reduce construction costs, two novel provisions - the hydraulic aeration and recirculation in the upper oxidation pond and the perforated flush piping in the lower oxic limestone drain-were eliminated. As shown in Fig. 2, the AMD from the Otto Discharge was diverted from the rock-lined ditch at about $235 \mathrm{~m}$ downstream from the tunnel and spilled sequentially into the oxidation pond, the two shallow wetlands, and finally the oxic limestone drain. Rectangular weirs with adjustable freeboard were installed between each of the treatment cells to control water levels and facilitate flow measurements. At the second wetland, an overflow weir was installed as a secondary outlet in the event the oxic limestone drain would not be able to transmit the entire flow.

\section{Materials and Methods}

\section{Water-Quality Sampling and Analysis}

Data on the flow rate and inorganic chemistry of the Otto Discharge and Muddy Branch above and below the Otto Discharge were collected by the USGS over a range of hydrologic conditions during 2001 to 2006 . Once treatment began, additional water-quality data were collected at the outlets of each of the treatment cells. After treatment was in place from late June 2005 to early June 2006, all the water from the Otto Discharge was diverted through the treatment system. Sample sites along the rock-lined diversion ditch from the Otto tunnel were at the inflow (Otto 235-m) and below the outflow (Otto 470-m) of the treatment system and, hence, useful to indicate the "untreated" and "treated" water quality, respectively. Monitoring site descriptions are reported in Table 1.

The flow rate of Muddy Branch above and below the Otto Discharge was measured by using a wading rod and pygmy current meter (Rantz et al. 1982a). After the treatment system 


\section{Aerobic Treatment System Components:}

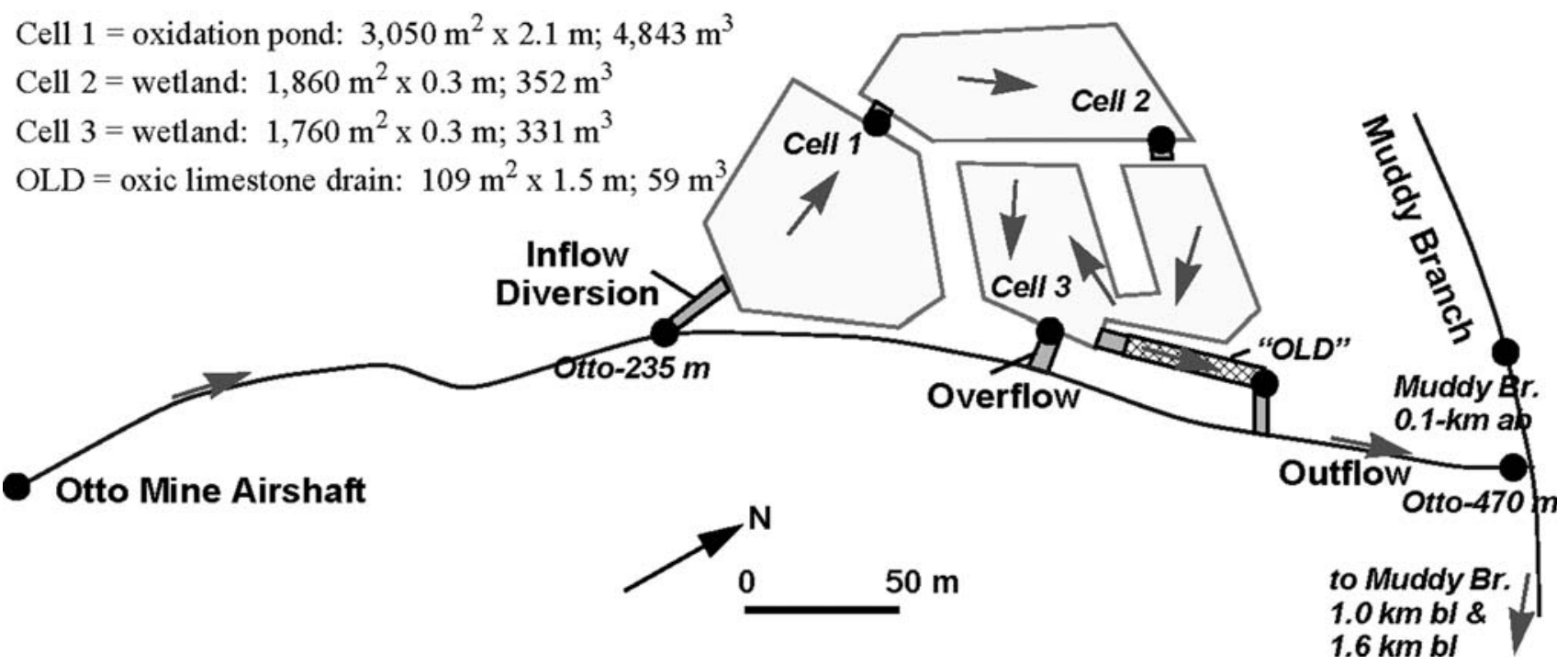

Fig. 2 Schematic plan of passive, aerobic treatment system constructed in 2005 at the Otto Discharge, Branchdale, Pa. Labelled point symbols (e.g., Otto-235 m) indicate water-quality sample sites; arrows indicate general flow direction through sequential treatment

stages; $a b$ above, $b l$ below. Data on the area and volume capacity are for the design dimensions, slopes, and surface-water elevations (Christine Haldeman and Clayton Bubeck, Rettew Associates, written communication, 2006)

was installed, weirs at the outlet of each treatment cell were used to estimate the flow rate throughout the treatment system. The flow across the weir notch was estimated on the basis of a standard equation for rectangular notch geometry (Rantz et al. 1982b) adapted for metric units:

Flow $\operatorname{rate}\left(\mathrm{L} \mathrm{s}^{-1}\right)=(1.839 \cdot$ width $) \cdot(\text { depth })^{1.5}$

where the width is $1.52 \mathrm{~m}$ and the water depth over the weir is in centimeters. To estimate detention time within each treatment cell, the volume of water contained within the cell (Fig. 2) was divided by the flow rate. The volumes were assumed constant because only minor changes in water depth were recorded at the weirs between cells compared to the total depths of the cells.

At each sample site, temperature, $\mathrm{pH}$, specific conductance (SC), dissolved oxygen (DO), and redox potential (Eh) were measured by using a multiparameter, submersible sonde. The sonde was calibrated daily in accordance with standard methods (U.S. Geological Survey 1997 to present). Field $\mathrm{pH}$ and Eh were determined by using a combination $\mathrm{Pt}$ and $\mathrm{Ag} / \mathrm{AgCl}$ electrode with a $\mathrm{pH}$ sensor. The electrode was calibrated in $\mathrm{pH} 4.0$ and 7.0

Table 1 Descriptions of water-quality monitoring sites on Muddy Branch and the Otto Discharge treatment system at Branchdale, Pa

\begin{tabular}{|c|c|c|c|c|}
\hline USGS Station ID & Site name and description & Longitude $^{\mathrm{a}}$ & Latitude & Elevation $^{\mathrm{b}} \mathrm{m}$ \\
\hline 403958076191401 & Otto Mine Tunnel at Branchdale & -76.32022 & 40.66620 & 250 \\
\hline 0146784348 & Otto 235 m "Inflow" & -76.31939 & 40.66758 & 244 \\
\hline 404001076191301 & Otto Treatment Cell 1 "Oxidation Pond" & -76.32033 & 40.66705 & 244 \\
\hline 404006076191001 & Otto Treatment Cell 2 "Wetland 1" & -76.31927 & 40.66803 & 244 \\
\hline 404005076190901 & Otto Treatment Cell 3 "Wetland 2" & -76.31956 & 40.66842 & 244 \\
\hline 404008076190601 & Otto Treatment Oxic Limestone Drain & -76.31842 & 40.66875 & 244 \\
\hline 0146784350 & Otto $470 \mathrm{~m}$ "Outflow" & -76.31828 & 40.66870 & 238 \\
\hline 0146784338 & Muddy Branch $0.1 \mathrm{~km}$ above Otto & -76.31861 & 40.66889 & 244 \\
\hline 0146784354 & Muddy Branch $1.0 \mathrm{~km}$ below Otto (PF 101), Steins Mill Rd & -76.30666 & 40.66750 & 232 \\
\hline 0146784358 & Muddy Branch $1.8 \mathrm{~km}$ below Otto (PF 102), Black Diamond Rd & -76.30278 & 40.66472 & 230 \\
\hline
\end{tabular}

Approximate site locations shown in Fig. 2

${ }^{\text {a }}$ Horizontal coordinate information is referenced to the North American Datum of 1983 (NAD 83)

b Elevations referenced to the National Geodetic Vertical Datum of 1929 (NGVD 29) 
buffer solutions and in ZoBell's solution (Wood 1976, pp. 18-22; U.S. Geological Survey 1997 to present). Values for $\mathrm{Eh}$ were corrected to $25^{\circ} \mathrm{C}$ relative to the standard hydrogen electrode in accordance with methods of Nordstrom (1977). Unfiltered and filtered $(0.45 \mu \mathrm{m}$ pore size $)$ samples of water were processed in the field, transferred to polyethylene bottles, preserved as appropriate, and transported on ice to the laboratory.

The alkalinity and "hot peroxide" acidity (hot acidity) of the unfiltered water samples were titrated using sulfuric acid $\left(\mathrm{H}_{2} \mathrm{SO}_{4}\right)$ and/or sodium hydroxide $(\mathrm{NaOH})$ to fixed endpoint pH of 4.5 and 8.3, respectively (American Public Health Association 1998a, 1998b). Typically, alkalinities were measured within $24 \mathrm{~h}$ of sampling, whereas acidities were measured several days later at the USGS Water Science Center laboratory in New Cumberland, Pennsylvania. Concentrations of major anions $\left(\mathrm{SO}_{4}, \mathrm{Cl}\right)$ in filtered, unpreserved subsamples were analyzed by ion chromatography (IC), and concentrations of major cations ( $\mathrm{Ca}, \mathrm{Mg}, \mathrm{Na}, \mathrm{K}$ ) and selected trace metals (Fe, Mn, Al, Ni, Zn) in unfiltered and filtered, acidified subsamples were analyzed by inductively coupled plasma optical emission spectrometry (ICP) at the Actlabs laboratory in Toronto, Ontario, or the USGS Mineral Resources Laboratory (MRL) in Denver, Colorado (Crock et al. 1999; Fishman and Friedman 1989).

To supplement data on hot acidity, the net acidity was computed as mg/L of $\mathrm{CaCO}_{3}$, considering positive acidity contributions from $\mathrm{pH}$ and concentrations of dissolved iron, manganese, and aluminum in $\mathrm{mg} / \mathrm{L}\left(C_{\mathrm{Fe}}, C_{\mathrm{Mn}}\right.$, and $C_{\mathrm{Al}}$, respectively), and negative contributions from alkalinity as $\mathrm{mg} / \mathrm{L}$ of $\mathrm{CaCO}_{3}$ :

$$
\begin{aligned}
& \text { NetAcidity } \\
& =50\left(10^{(3-\mathrm{pH})}+2 \cdot C_{\mathrm{Fe}} / 55.85+2 \cdot C_{\mathrm{Mn}} / 54.94+3 \cdot C_{\mathrm{Al}} / 26.98\right) \\
& - \text { Alkalinity }
\end{aligned}
$$

Kirby and Cravotta (2005a, b) showed that net acidity computed with Eq. 4 is comparable in value to the standard method hot acidity where the $\mathrm{H}_{2} \mathrm{SO}_{4}$ added to the sample is subtracted from the $\mathrm{NaOH}$ added (American Public Health Association 1998a).

Annual aquatic ecological surveys were conducted in October 2002, 2003, 2004, and 2005 on Muddy Branch at one site immediately upstream and two sites downstream from the confluence with the Otto Discharge. The two downstream stations (PF 101 and PF 102 in Table 1) were surveyed previously by the Pennsylvania Fish and Boat Commission (Chikotas and Kaufman 2002). Fish were collected by electrofishing over a 150-m reach consisting of mixed riffle, run, and pool habitats at each stream site, held for measurement and identification, checked for anomalies, and then released in accordance with methods described by Barbour et al. (1999) and Meador et al. (1993). Although benthic-macroinvertebrate samples also were collected during the annual surveys, sample processing and taxonomic identification were not completed at the time of this report (2007).

\section{Laboratory Aeration Experiment}

A laboratory aeration experiment with AMD from the Otto Discharge was conducted in December 2001 to determine the potential rate of iron removal and to verify that the $\mathrm{pH}$ could be sustained near neutrality without supplemental alkalinity. On the morning of December 3, 2001, raw water and corresponding field measurements of water quality were collected from the discharge as it exited the Otto Mine tunnel. A total of $30 \mathrm{~L}$ of raw water was collected in a $66 \mathrm{~L}$ capacity plastic cooler and immediately transported to the author's residence. An aquarium pump with porous stone diffuser set at the bottom of the cooler delivered a continuous air-flow rate of $1.5 \mathrm{~L} / \mathrm{min}$; the rising air bubbles promoted aeration and circulation of the water and suspended fine particles. The ambient temperature of the initial sample, $12.3^{\circ} \mathrm{C}$, was approximately maintained during the aeration experiment $\left(10.5-13.7^{\circ} \mathrm{C}\right)$. A multiparameter sonde was submerged at the bottom of the cooler to record temperature, $\mathrm{pH}, \mathrm{SC}, \mathrm{DO}, \mathrm{Eh}$, and turbidity. Serial sampling was conducted to evaluate changes in alkalinity, acidity, and concentrations of metals. At fixed time intervals, a $500 \mathrm{~mL}$ polyethylene bottle was immersed opposite the aerator and its contents were processed for chemical analysis. Alkalinity and "cold peroxide" acidity (cold acidity) in unfiltered samples were measured in USGS New Cumberland office. The cold acidity includes contributions from the dissolved $\mathrm{CO}_{2}$ plus dissolved iron and aluminum but may exclude contributions from manganese (Kirby and Cravotta 2005a, b); hot acidity was not measured because the computed net acidity (Eq. 4) was assumed to provide equivalent information. Concentrations of dissolved ( $0.22 \mu \mathrm{m}$ filter) and total metals in acidified samples were measured by ICP at the U.S. Department of Energy laboratory in Pittsburgh, Pennsylvania.

\section{Geochemical Models of Iron-Oxidation Rates}

Various kinetic oxidation models that considered effects of detention time (travel time), $\mathrm{pH}, \mathrm{O}_{2}$, and $\mathrm{Fe}^{2+}$ concentration were used to evaluate the data for the laboratory aeration experiment and the Otto treatment system. Stumm and Lee (1961) proposed a widely cited rate law for the abiotic oxidation of $\mathrm{Fe}^{2+}$ under laboratory conditions: 
$\mathrm{d}\left[\mathrm{Fe}^{2+}\right] / \mathrm{dt}=-\mathrm{k}\left[\mathrm{Fe}^{2+}\right]\left[\mathrm{OH}^{-}\right]^{2} \mathrm{PO}_{2}$,

where $\left[\mathrm{Fe}^{2+}\right]$ denotes concentration (in $\mathrm{mol} / \mathrm{L}$ ) and $\mathrm{k}$ is the rate constant, $1.33 \times 10^{12} \mathrm{~L}^{2} /\left(\mathrm{mol}^{2}\right.$ atm s). Equation 5 indicates the abiotic oxidation of $\mathrm{Fe}^{2+}$ is strongly dependent on $\mathrm{pH}$; the rate increases by a factor of 100 with each unit increase in $\mathrm{pH}$. In contrast, Williamson et al. (1992) reported that the biological oxidation rate for $\mathrm{Fe}^{2+}$ in surface waters receiving AMD is independent of $\mathrm{pH}$ over the range 2.5-6.0 and faster than the abiotic oxidation rate as indicated by:

$\mathrm{d}\left[\mathrm{Fe}^{2+}\right] / \mathrm{d} t=-k\left[\mathrm{Fe}^{2+}\right]$,

where the rate constant is $10^{-3.61} \mathrm{~s}^{-1}$.

For this study, the two oxidation models were evaluated in a spreadsheet by solving the integrated form of Eqs. 5 and 6:

$[\mathrm{Fe}]_{t}=[\mathrm{Fe}]_{t=0} \exp \left\{-k^{\prime} \cdot t\right\}$

where $k^{\prime}$ for the integrated form of Eq. 5 includes specified constant values of $\mathrm{pH}$ and $\mathrm{PO}_{2}$. For the specified initial concentration of $\mathrm{Fe}^{2+}$, the spreadsheet models computed the concentration of residual $\mathrm{Fe}^{2+}$ as a function of elapsed time, $t$. The spreadsheet models, equivalent to the modeling approach used in the "AMDTreat" model for mine-drainage treatment (U.S. Office of Surface Mining Reclamation and Enforcement 2002), did not consider effects on the rate constant owing to variations in the iron concentration, $\mathrm{pH}$, or temperature as oxidation progresses.

To evaluate interactions among the dissolved iron concentration and oxidation state, $\mathrm{pH}$, alkalinity, and other variables, the two kinetic models of $\mathrm{Fe}^{2+}$ oxidation (Eqs. 5, 6) also were used in the geochemical computer program PHREEQC (Parkhurst and Appelo 1999). This model, given in Appendix A (in Electronic supplementary material), was adapted from "Example 9-Kinetically controlled oxidation of ferrous iron" provided by the PHREEQC authors. Initial models for this study assumed constant, equilibrium values of $\mathrm{PO}_{2}$ and/or $\mathrm{PCO}_{2}$ and limited concentrations of dissolved $\mathrm{Fe}^{3+}$ to equilibrium with amorphous $\mathrm{Fe}(\mathrm{OH})_{3}$. Subsequent models simulated atmospheric disequilibrium with respect to $\mathrm{CO}_{2}$ by incorporating a term for the observed asymptotic decrease in $\mathrm{PCO}_{2}$ during the aeration experiment. The geochemical program WATEQ4F version 2.63 (Ball and Nordstrom 1991), which is useful to compute equilibrium speciation for large sample sets, was used to compute the $\mathrm{PCO}_{2}, \mathrm{PO}_{2}$, and saturation index (SI) values for selected minerals. The $\mathrm{PCO}_{2}$ was computed on the basis of measured $\mathrm{pH}$, alkalinity, and temperature. The activities of ferrous and ferric species were computed on the basis of the measured dissolved iron, Eh, and temperature of fresh samples. For consistency, the thermodynamic database used by WATEQ4F was used for the PHREEQC simulations.

\section{Results: Laboratory and Field Observations}

\section{Laboratory Aeration Experiment}

Initially, the Otto Discharge sampled for the aeration experiment was colorless and anoxic, with $\mathrm{pH}$ of 5.8 and dissolved iron concentration of $16.4 \mathrm{mg} / \mathrm{L}$. Aggressive aeration promoted the rapid oxidation of dissolved $\mathrm{Fe}^{2+}$; freshly precipitated, suspended $\mathrm{Fe}(\mathrm{OH})_{3}$ particles temporarily changed the water to a deep orange-brown color. In less than $24 \mathrm{~h}$, the initial $\mathrm{Fe}^{2+}$ concentration of $16.4 \mathrm{mg} / \mathrm{L}$ decreased to less than $0.5 \mathrm{mg} / \mathrm{L}$ (Fig. 3a). Nevertheless, the concentrations of total iron declined slowly because of slow settling of $\mathrm{Fe}(\mathrm{OH})_{3}$ particles. The abundance of suspended $\mathrm{Fe}(\mathrm{OH})_{3}$ particles was indicated by the turbidity, which increased from zero to a maximum value of 230 nephelometric turbidity units (NTU) after $12 \mathrm{~h}$ of aeration and then gradually declined as the $\mathrm{Fe}(\mathrm{OH})_{3}$ settled from suspension (Fig. 3a). After 4.5 days of continuous aeration, most $\mathrm{Fe}(\mathrm{OH})_{3}$ particles had settled to the bottom of the cooler and the supernatant was again colorless.

Once aggressive aeration began ( $1 \mathrm{~h}$ after collection), the DO increased to saturation (Fig. 3c). Although the cold temperature of the discharge water was maintained during the aeration experiment $\left(10.5-13.7^{\circ} \mathrm{C}\right)$, aeration promoted evaporation and the exsolution of dissolved $\mathrm{CO}_{2}$. The $\mathrm{SC}$, which indicates dissolved solute concentrations, declined during the first $12 \mathrm{~h}$ of aeration due to the precipitation of $\mathrm{Fe}(\mathrm{OH})_{3}$ and the conversion of $\mathrm{HCO}_{3}^{-}$to $\mathrm{CO}_{2}$ :

$\mathrm{Fe}^{2+}+0.25 \mathrm{O}_{2}+2 \mathrm{HCO}_{3}^{-}+0.5 \mathrm{H}_{2} \mathrm{O}=\mathrm{Fe}(\mathrm{OH})_{3}+2 \mathrm{CO}_{2}(\mathrm{~g})$

but thereafter increased in accordance with the sulfate concentrations (Fig. 3b). Because of evaporation, concentrations of sulfate increased by about 5\% during the experiment.

Despite the nearly complete oxidation and hydrolysis of iron, net-alkaline character was maintained during the aeration experiment. Initially, the Otto Discharge had $\mathrm{pH}$ of 5.8 , cold acidity of $122 \mathrm{mg} / \mathrm{L}$, alkalinity of $70 \mathrm{mg} / \mathrm{L}$, and net acidity (Eq. 4) of $-35.9 \mathrm{mg} / \mathrm{L}$ as $\mathrm{CaCO}_{3}$ (Fig. 3d, e). Once aeration began, the $\mathrm{pH}$ increased and the cold acidity decreased owing to the rapid exsolution of $\mathrm{CO}_{2}$ (Eqs. 2, 8). Within $12 \mathrm{~h}$, the $\mathrm{pH}$ increased to values of 7.0 or more (Fig. 3d), ultimately attaining a steady-state value of 7.5. Proton acidity generated with the hydrolysis of iron (Eq. 1) was neutralized by the initial excess alkalinity (Eq. 8), causing the alkalinity to decline to a steady-state 

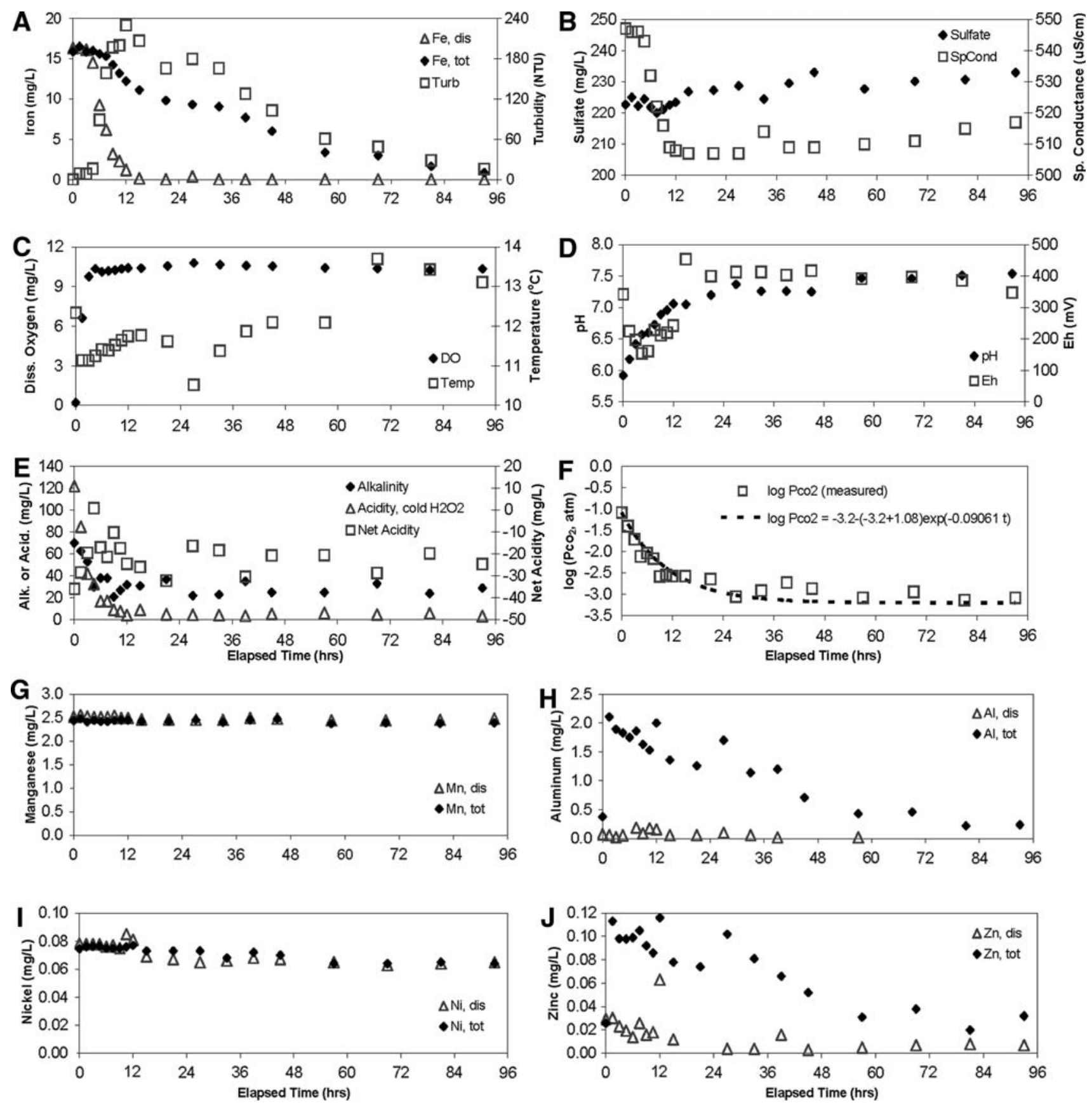

Fig. 3 Time-series plots of the quality of water during laboratory aeration experiment on the Otto Discharge conducted December 3-7, 2001. a Iron and turbidity; b sulfate and specific conductance; c dissolved oxygen and temperature; $\mathbf{d ~ p H}$ and $\mathrm{Eh}$; e alkalinity, cold

acidity, and net acidity; $\mathbf{f}$ measured and estimated partial pressure of carbon dioxide $\left(\mathrm{PCO}_{2}\right)$ computed with Eq. 12; g, manganese; $\mathbf{h}$ aluminum; i nickel; $\mathbf{j}$ zinc. Values below detection limits were plotted as negative (below axis)

concentration of approximately $30 \mathrm{mg} / \mathrm{L}$ as $\mathrm{CaCO}_{3}$ and the net acidity to increase to approximately $-25 \mathrm{mg} / \mathrm{L}$ as $\mathrm{CaCO}_{3}$ (Fig. 3e).

The rapid, asymptotic increase in $\mathrm{pH}$ coincided with an asymptotic decrease in the $\mathrm{PCO}_{2}$ from an initial $\mathrm{PCO}_{2}$ value of $10^{-1.1} \mathrm{~atm}$ to a steady-state value of $10^{-3.2} \mathrm{~atm}$

(Fig. 3f). The inverse correlation between $\mathrm{pH}$ and $\mathrm{PCO}_{2}$ indicates the potential for $\mathrm{PCO}_{2}$ to determine $\mathrm{pH}$ and, hence, $\mathrm{Fe}^{2+}$-oxidation rates. To compute $\mathrm{PCO}_{2}$ as a function of elapsed time for the aeration experiment, the empirical $\log \left(\mathrm{PCO}_{2}\right)$ data were fit with an exponential equation of the form: 
$\mathrm{d} C / \mathrm{d} t=k\left(C_{\mathrm{S}}-C_{0}\right)$

where $C_{0}$ is the initial value and $C_{\mathrm{S}}$ is the steady-state value for $\log \left(\mathrm{PCO}_{2}\right)$. Integration of Eq. 9 for a first-order reaction yields:

$\ln \left[\left(C_{\mathrm{S}}-C_{\mathrm{t}}\right) /\left(C_{\mathrm{S}}-C_{0}\right)\right]=-k \cdot t$

where $C_{\mathrm{t}}$ is the $\log \left(\mathrm{PCO}_{2}\right)$ value at any time $(t)$. Linear regression of $\ln \left[\left(C_{\mathrm{S}}-C_{\mathrm{t}}\right) /\left(C_{\mathrm{S}}-C_{0}\right)\right]$ versus elapsed time for the $\log \left(\mathrm{PCO}_{2}\right)$ data through $15 \mathrm{~h}$ of the aeration experiment yielded an estimate for $k$ of $0.0906 \mathrm{~h}^{-1}$. Taking the antilogarithm and rearranging Eq. 10 yields:

$C_{\mathrm{t}}=C_{\mathrm{S}}-\left[\left(C_{\mathrm{S}}-C_{0}\right) \cdot \exp \{-k \cdot t\}\right]$

After substituting the empirical constant values for $C_{\mathrm{S}}$, $C_{0}$, and k, the $\log \left(\mathrm{PCO}_{2}\right)$ as a function of elapsed time could be estimated:

$\log \left(\mathrm{PCO}_{2}\right)=-3.2-(-3.2+1.08) \cdot \exp \{-0.0906 \cdot t\}$

The dashed curve through observed data for the aeration experiment (Fig. 3f) was computed accordingly. As explained later, geochemical kinetic models of $\mathrm{Fe}^{2+}$ oxidation utilized the above Eqs. 11 and 12 to estimate variable, disequilibrium $\mathrm{PCO}_{2}$ and associated $\mathrm{pH}$ values.

Although dissolved iron was attenuated by continuous aeration, concentrations of total and dissolved manganese remained nearly constant at $2.5 \mathrm{mg} / \mathrm{L}$ for the duration of the 4.5-day experiment (Fig. 3g). The residual cold acidity of $5 \mathrm{mg} / \mathrm{L}$ (Fig. 3e) can be attributed to the persistence of dissolved manganese $\left(\mathrm{Mn}^{2+}\right)$. Nevertheless, sufficient alkalinity remained to neutralize this potential acidity as indicated by the negative values for net acidity (Fig. 3e). Previous work indicates that the oxidation and removal of manganese from AMD may require 20 times larger wetland area than that required to remove an equivalent amount of iron (Hedin et al. 1994). Other work indicates that manganese removal may be facilitated with a limestone substrate (Cravotta and Trahan 1999) or by the addition of strong alkaline or oxidizing agents (e.g., Tewalt et al. 2005).

Concentrations of dissolved aluminum initially were low $(0.08 \mathrm{mg} / \mathrm{L})$, as expected because of low solubility of aluminum hydroxide $\left(\mathrm{Al}(\mathrm{OH})_{3}\right)$ in near-neutral solutions (e.g., Langmuir 1997; Cravotta 2007). Nevertheless, white precipitate on rocks at the discharge was inadvertently dislodged during sampling for the aeration experiment. Elevated concentrations of total aluminum during the aeration experiment (Fig. 3h) reflect the persistence of this suspended $\mathrm{Al}(\mathrm{OH})_{3}$, which slowly settled over the 4.5-day test. The trends for concentrations of total and dissolved zinc (Fig. 3j) paralleled those for aluminum; the $\mathrm{Al}(\mathrm{OH})_{3}$ precipitate could be a sorbent for zinc (e.g., Coston et al.1995). Although elevated concentrations of total zinc near the start of the experiment were comparable to the USEPA criteria continuous concentration value of $0.12 \mathrm{mg} / \mathrm{L}(120 \mu \mathrm{g} / \mathrm{L})$ for protection of freshwater aquatic organisms (U.S. Environmental Protection Agency 2002), concentrations of dissolved zinc $(<0.03 \mathrm{mg} / \mathrm{L})$ were substantially below the aquatic protection criteria and declined during the test.

Concentrations of total and dissolved nickel decreased by almost $20 \%$ during the experiment (Fig.3i). Nevertheless, the concentrations of dissolved nickel at the beginning and end of the experiment $(0.078$ and $0.065 \mathrm{mg} / \mathrm{L}$, respectively) exceeded the USEPA criteria continuous concentration value of $0.052 \mathrm{mg} / \mathrm{L}(52 \mu \mathrm{g} / \mathrm{L})$ for protection of freshwater aquatic organisms (U.S. Environmental Protection Agency 2002). Previous work indicates that nickel could be adsorbed or coprecipitated with iron and manganese oxides (e.g., McKenzie 1980; Cravotta and Trahan 1999).

\section{Muddy Branch above and below the Otto Discharge}

Time-series plots (Fig. 4) summarize flow and waterquality data for Muddy Branch during the period 2 years before and 1 year after the Otto Discharge treatment system began operation. For reference, the plots also display data for the untreated Otto AMD during the period 2 years before (Otto tunnel) and 1 year after (Otto 235-m) the treatment system began operation and the data for corresponding untreated or treated effluent $470 \mathrm{~m}$ below the tunnel (Otto 470-m) at the confluence with Muddy Branch.

During most sampling events, the flow of water in Muddy Branch above the Otto Discharge was smaller than that of the Otto Discharge (Fig. 4a). Hence, the flow and quality of water in Muddy Branch below the Otto Discharge were greatly affected by the discharge, particularly during low base-flow conditions. Flow from the Otto Discharge accounted for more than $80 \%$ of the flow of Muddy Branch during the summer of 2004 and the fall of 2005 . Because the Otto Discharge at its confluence with Muddy Branch (Otto 470-m) typically had pH and DO concentrations that were comparable to those upstream for Muddy Branch (Fig. 4b, d), these characteristics of Muddy Branch at downstream sites generally were unaffected. However, other characteristics differed between the Otto Discharge and Muddy Branch sites.

Before the treatment system was installed, the Otto Discharge had a nearly constant temperature of $12^{\circ} \mathrm{C}$; the temperature of Muddy Branch varied seasonally (Fig. 4c). Muddy Branch above the Otto Discharge had temperatures approaching $5^{\circ} \mathrm{C}$ in winter and $17^{\circ} \mathrm{C}$ in summer. Because 

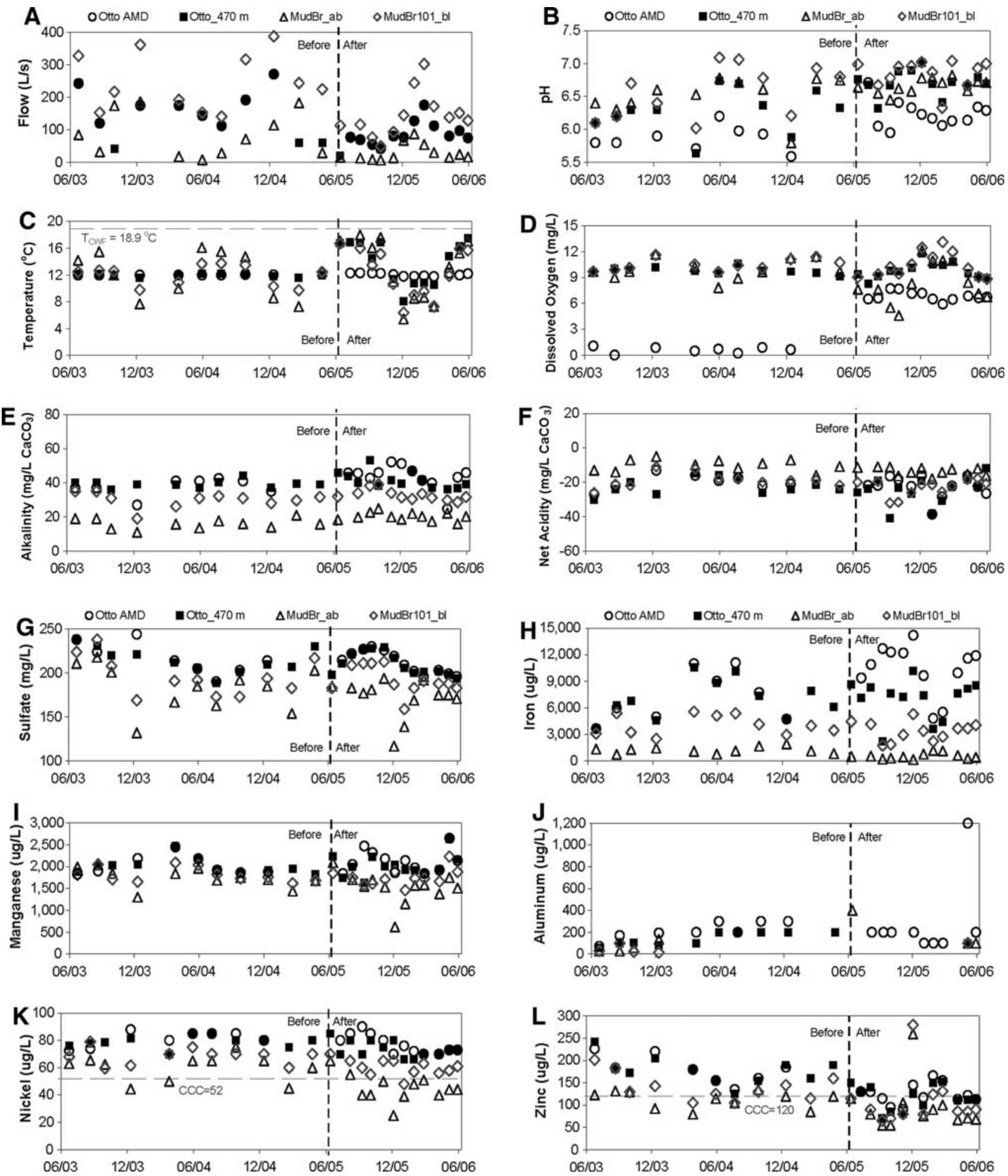

Fig. 4 Time-series plots of water quality at the Otto Mine (Otto AMD, Otto_470 m) and Muddy Branch above (MudBr_ab) and below (MudBr_bl) the Otto Discharge before (June 2003-June 2005) and after (June 2005-June 2006) treatment installed. a Flow rate; b $\mathrm{pH}$; c temperature; $\mathbf{d}$ dissolved oxygen; e alkalinity; $\mathbf{f}$ net acidity; g sulfate; $\mathbf{h}$ dissolved iron; $\mathbf{i}$ dissolved manganese; $\mathbf{j}$ dissolved

aluminum; k dissolved nickel; I dissolved zinc. Values below detection were plotted as negative (below axis). $T_{\mathrm{CWF}}$ is maximum temperature permitted for streams designated cold-water fisheries (Commonwealth of Pennsylvania 2002); CCC is criteria continuous concentration for freshwater organisms (U.S. Environmental Protection Agency 2002) 
of the influence of the Otto Discharge, the temperature of Muddy Branch in downstream reaches was moderated to be warmer in the winter and cooler in the summer than upstream. However, after the Otto Discharge was routed through the treatment system, the effluent temperature changed in response to seasonal conditions. Consequently, beginning in June 2005, the temperature of Muddy Branch below the Otto Discharge exhibited greater seasonal temperature variability and closely matched that of the upstream water (Fig. 4c).

The alkalinity, sulfate, and metals concentrations of the Otto Discharge were greater and the net acidity smaller than those for Muddy Branch above the discharge (Fig. 4e-1). Hence, Muddy Branch below the Otto Discharge had intermediate concentrations of these constituents reflecting its origin as a mixture of the two upstream sources. Small, if any, decreases in concentrations of iron and other metals in Muddy Branch resulted after treatment of the Otto Discharge. Although the Muddy Branch above the discharge was relatively dilute, it was not pristine. Concentrations of sulfate exceeding $100 \mathrm{mg} / \mathrm{L}$ and elevated concentrations of manganese, nickel, and zinc indicate probable effects from other AMD sources above the Otto Discharge (Fig. 1).

Before and after construction of the treatment system, concentrations of dissolved nickel and zinc in Muddy Branch frequently exceeded the U.S. Environmental Protection Agency (2002) criteria continuous concentration (CCC) values of 52 and $120 \mu \mathrm{g} / \mathrm{L}$, respectively, for protection of freshwater aquatic organisms (Fig. 4k, 1). Nevertheless, fish surveys conducted in 2002 through 2005 indicated five different fish species inhabited Muddy Branch below the Otto Discharge, whereas no fish were present above the discharge (Table 2). The fish species identified were characterized by Barbour et al. (1999) as tolerant to moderately tolerant of pollution. Brook trout (Salvelinus fontinalis), blacknose dace (Rhinichthys atratulus), and creek chub (Semotilus atromaculatus), which can be found in relatively low-pH waters draining uplands across Pennsylvania (Butler et al. 1973), were the dominant species (Table 2). Fewer fish were present at Muddy Branch site PF101 (1.0 km downstream) than at site PF102 (1.6 km downstream); Muddy Branch became progressively larger downstream from the Otto Discharge and offered deeper pools and better habitat than at the upstream sites.

The fish survey data could be interpreted to indicate that treatment of the Otto Discharge did not harm the existing fish populations in Muddy Branch. Brook trout and blacknose dace are considered "cold-water fish" by the Pennsylvania Fish and Boat Commission (Chikotas and Kaufman 2002). Streams designated as cold-water fisheries in Pennsylvania must have temperatures less than $18.9^{\circ} \mathrm{C}$ during July and August (warmest months) and DO greater than $5.0 \mathrm{mg} / \mathrm{L}$ at all points in the stream (Commonwealth of Pennsylvania 2002). After treatment, the Otto Discharge (Otto 470-m) had a maximum temperature of $17.5^{\circ} \mathrm{C}$ and a minimum DO of $8.3 \mathrm{mg} / \mathrm{L}$ (Fig. 4c, d; Table 3). Equivalent numbers of fish species and individual fish were identified in 2005 compared to prior years (Table 2). Thus, the temperature fluctuations that became more extreme after construction of the Otto Discharge treatment system did not have obvious negative effects on the populations of brook trout and other resident cold-water fish species in Muddy Branch. Nevertheless, continued monitoring of fish populations in Muddy Branch would be needed to assess long-term effects from treatment of the Otto Discharge, with particular attention to low-flow conditions associated with summer drought.

\section{Otto Discharge Treatment System}

During the first year of operation, the entire flow of the Otto Discharge was routed through the treatment system. Although none bypassed the oxidation pond and wetlands, the majority of the effluent from the third cell (wetland 2) exited the overflow spillway to the drainage ditch instead of passing through the oxic limestone drain (Fig. 2). After the first month, the oxic limestone drain clogged with $\mathrm{Fe}(\mathrm{OH})_{3}$ precipitate and plant material and was not capable of transmitting the entire flow of water treated by the wetland cells. About $100 \mathrm{~m}$ downstream from the overflow and $50 \mathrm{~m}$ upstream from Muddy Branch, the effluent from the oxic limestone drain mixed with that already in the drainage ditch. The combined effluent was sampled at the Otto 470-m site. After the treatment system began operation, sampling of the Otto tunnel was replaced by sampling at the Otto 235-m inflow to the treatment system. Hence, the overall treatment-system performance is indicated by comparing water-quality data for the Otto tunnel or Otto 235-m (Otto AMD) with that for Otto 470-m (treated outflow plus any bypass or overflow) (Fig. 4).

During the period June 2003 to June 2006, flow from the Otto Mine ranged from 20 to 272 L/s (Fig. 4a). Generally, the $\mathrm{pH}$ and dissolved concentrations of sulfate, metals, and other constituents were not correlated with flow. Above the inflow to the treatment system (Otto AMD), SC ranged from 430 to $560 \mu \mathrm{S} / \mathrm{cm}$, and $\mathrm{pH}$ ranged from 5.5 to 6.6 (Fig. 4b). Because of hydraulic aeration within the rocklined drainage channel, the DO and $\mathrm{pH}$ increased as the AMD flowed to Muddy Branch. Before the treatment system was constructed, the $\mathrm{pH}$ increased about 0.5 units and the DO increased from $<1 \mathrm{mg} / \mathrm{L}$ to approximately $10 \mathrm{mg} / \mathrm{L}$ as the AMD reached the confluence with Muddy Branch (Otto 470-m); however, the temperature and concentrations of sulfate, iron, manganese, nickel, and zinc 
Table 2 Fish species identified and number of individuals counted during annual ecological surveys of Muddy Branch above and below the Otto Discharge near Branchdale, PA, USA, 2002-2005

\begin{tabular}{|c|c|c|c|c|c|c|c|c|c|c|c|c|c|c|}
\hline \multicolumn{2}{|l|}{ Taxa } & \multirow{3}{*}{$\begin{array}{l}\text { Min. pH } \\
\text { in } \mathrm{PA}^{\mathrm{a}}\end{array}$} & \multirow[t]{3}{*}{$\mathrm{PT}^{\mathrm{b}}$} & \multicolumn{11}{|c|}{ Number counted on Muddy Branch at USGS Station } \\
\hline $\begin{array}{l}\text { Order } \\
\text { Family }\end{array}$ & $\begin{array}{l}\text { Common } \\
\text { name }\end{array}$ & & & \multicolumn{3}{|c|}{$\begin{array}{l}\text { Above Otto } \\
0146784338\end{array}$} & \multicolumn{4}{|c|}{$\begin{array}{l}\text { Below Otto "PF101" } \\
0146784354\end{array}$} & \multicolumn{4}{|c|}{$\begin{array}{l}\text { Below Otto “PF102” } \\
0146784358\end{array}$} \\
\hline Genus species & & & & 03 & 04 & 05 & 02 & 03 & 04 & 05 & 02 & 03 & 04 & 05 \\
\hline \multicolumn{15}{|l|}{ Cypriniformes } \\
\hline \multicolumn{15}{|l|}{ Cyprinidae } \\
\hline Rhinichthys atratulus & Blacknose dace & 5.6 & $\mathrm{~T}$ & 0 & 0 & 0 & 1 & 0 & 0 & 2 & 12 & 10 & 0 & 15 \\
\hline Semotilus atromaculatus & Creek chub & 5.2 & $\mathrm{~T}$ & 0 & 0 & 0 & 0 & 0 & 0 & 0 & 11 & 12 & 3 & 11 \\
\hline \multicolumn{15}{|l|}{ Catostomidae } \\
\hline Catostomus commersoni & White sucker & 4.6 & $\mathrm{~T}$ & 0 & 0 & 0 & 0 & 0 & 0 & 0 & 10 & 12 & 0 & 0 \\
\hline \multicolumn{15}{|l|}{ Salmoniformes } \\
\hline \multicolumn{15}{|l|}{ Salmonidae } \\
\hline Salvelinus fontinalis & Brook trout & 5.0 & M & 0 & 0 & 0 & 8 & 3 & 0 & 9 & 32 & 39 & 3 & 28 \\
\hline \multicolumn{15}{|l|}{ Perciformes } \\
\hline \multicolumn{15}{|l|}{ Centrarchidae } \\
\hline Lepomis cyanellus & Green sunfish & 6.4 & $\mathrm{~T}$ & 0 & 0 & 0 & 0 & 0 & 0 & 0 & 0 & 0 & 0 & 1 \\
\hline \multicolumn{4}{|c|}{ Total number of individuals collected: } & 0 & 0 & 0 & 9 & 3 & 0 & 11 & 65 & 73 & 6 & 55 \\
\hline \multicolumn{4}{|c|}{ Total number of species identified: } & 0 & 0 & 0 & 2 & 1 & 0 & 2 & 4 & 4 & 2 & 4 \\
\hline
\end{tabular}

Fish collected and identified by M. D. Bilger and R. A. Brightbill of U.S. Geological Survey

${ }^{a}$ Minimum $\mathrm{pH}$ of occurrence in freshwater in Pennsylvania as reported by Butler et al. (1973)

${ }^{\mathrm{b}}$ Pollution tolerance (PT): I (intolerant), M (moderate), T (tolerant), adapted from Barbour et al. (1999)

changed little (Fig. 4). After treatment began in June 2005, the net acidity and concentrations of sulfate, manganese, nickel, and zinc did not change appreciably between the upstream (Otto 235-m) and downstream (Otto 470-m) sites; however, the temperature and concentrations of dissolved iron changed substantially (Figs. 4, 5). After treatment, temperature increased during the summer months (June through August) to a maximum of $17.5^{\circ} \mathrm{C}$ and decreased during late fall through early spring months to a minimum of $8.1^{\circ} \mathrm{C}$ (Figs. $4 \mathrm{c}, 5 \mathrm{c}$ ). Treatment also caused a marked reduction in the concentration of dissolved iron (Figs. 4, 5). The concentrations of dissolved iron decreased an average of $34 \%$, while those for manganese decreased by only $1.9 \%$; reductions in aluminum concentrations could not be quantified because the downstream concentrations were mostly below detection (Figs. 4j, 5j).

Monthly data for samples collected at the outflow from each of the treatment cells during the first year of operation, July 2005 through June 2006 (Fig. 5; Table 3), provide information about effects of specific stages of the treatment system. Data for cells 1, 2, and 3 correspond with the effluent from the oxidation pond, first wetland, and second wetland, respectively (Figs. 2, 5).

When synoptic samples were collected, flow rates through the treatment system ranged from 79.6 to $177 \mathrm{~L} / \mathrm{s}$ (Table 3, Fig. 5a). Corresponding, cumulative detention times within the treatment system ranged from 37 to $9 \mathrm{~h}$ (Table 3). Because of its larger volume, estimated detention times were more than 10 times greater for the oxidation pond, $4,843 \mathrm{~m}^{3}$, compared to the two shallow wetlands, 352 and $331 \mathrm{~m}^{3}$ (Fig. 2). Generally, the DO and $\mathrm{pH}$ increased and concentrations of dissolved iron and alkalinity decreased progressively through the treatment system (Fig. 5). If iron removal and alkalinity consumption were exactly balanced (Eq. 8), the acidity due to metals and the alkalinity of influent would decrease in tandem resulting in no net change in the net-acidity concentrations (Eq. 4). With the exception of samples collected in September 2005 and April 2006, the net acidity remained relatively constant through the treatment system (Fig. 5f). The largest changes in water quality typically occurred within the oxic limestone drain where the dissolution of limestone produced increases in $\mathrm{pH}$ and alkalinity and corresponding decreases in net acidity. Although effective for adding alkalinity and removing iron, manganese, nickel, and zinc (Fig. 5), the oxic limestone drain treated only a fraction of the flows transmitted through the wetland cells. Long detention times in the oxic limestone drain (Table 3) reflect its diminished flow rate after it clogged.

Hundreds of metric tons of sulfate, calcium, acidity, iron, and other constituents were transported from the Otto Mine tunnel to the treatment system during the first year of 
Table 3 Summary of water-quality data for the Otto Discharge treatment system at Branchdale, PA, USA, July $2005-J u n e$ 2006 [values are median (minimum/maximum); "<" less than; "nd" no data; "SI" saturation index]

\begin{tabular}{|c|c|c|c|c|c|c|}
\hline Constituent & $\begin{array}{l}\text { Otto } 235 \mathrm{~m} \\
\text { Inflow } \\
0146784348\end{array}$ & $\begin{array}{l}\text { Cell } 1 \text { Pond } \\
404001076191301\end{array}$ & $\begin{array}{l}\text { Cell } 2 \text { Wetland } \\
404006076191001\end{array}$ & $\begin{array}{l}\text { Cell } 3 \text { Wetland } \\
404005076190901\end{array}$ & $\begin{array}{l}\text { Oxic Drain } \\
404008076190601\end{array}$ & $\begin{array}{l}\text { Otto } 470 \mathrm{~m} \\
\text { Outflow } \\
0146784350\end{array}$ \\
\hline Flow (L/s) & $79.6(42.2 / 177)$ & $79.6(42.2 / 177)$ & $79.6(42.2 / 177)$ & $75.1(30.3 / 174)$ & $3.68(<0.05 / 32.9)$ & $79.6(42.2 / 177)$ \\
\hline $\begin{array}{l}\text { Detention time } \\
\text { (hr) }\end{array}$ & $0.08(0.03 / 0.14)$ & $17(7.6 / 31.9)$ & $1.25(0.6 / 2.3)$ & $1.25(0.5 / 3.0)$ & $5.0(0.5 / 583)$ & $<0.01(<0.0 / 0.10)$ \\
\hline $\begin{array}{l}\text { Travel time, cum } \\
\text { (hr) }\end{array}$ & $0.08(0.03 / 0.14)$ & $17(7.6 / 32.0)$ & $18.2(8.2 / 34.3)$ & $19.8(8.7 / 37.1)$ & nd & $19.9(8.8 / 37.2)$ \\
\hline Temp (C) & $12.1(11.8 / 12.3)$ & $13.1(10.0 / 16.1)$ & $14.7(8.9 / 17.5)$ & $15.8(8.4 / 18.4)$ & $11.7(7.3 / 15.5)$ & $14.6(8.1 / 17.5)$ \\
\hline $\begin{array}{l}\text { Oxygen, diss. } \\
(\mathrm{mg} / \mathrm{L})\end{array}$ & $6.7(5.9 / 7.7)$ & $8.9(7.4 / 10.0)$ & $9.4(7.8 / 11.2)$ & $10.1(8.7 / 11.7)$ & $8.1(4.6 / 10.4)$ & $9.8(8.3 / 11.8)$ \\
\hline $\mathrm{Eh}(\mathrm{mv})$ & $320(219 / 560)$ & $330(209 / 547)$ & $327(217 / 519)$ & $357(197 / 508)$ & $400(212 / 575)$ & $310(182 / 459)$ \\
\hline $\begin{array}{l}\text { Sp. Cond. } \\
(\mu \mathrm{S} / \mathrm{cm})\end{array}$ & $517(484 / 553)$ & $514(483 / 548)$ & $514(482 / 544)$ & $513(479 / 546)$ & $547(484 / 603)$ & $512(428 / 556)$ \\
\hline pH (units) & $6.2(6.0 / 6.4)$ & $6.5(6.1 / 6.6)$ & $6.5(6.2 / 6.8)$ & $6.5(6.1 / 6.9)$ & $6.8(6.4 / 7.2)$ & $6.7(6.3 / 7.0)$ \\
\hline $\begin{array}{l}\text { Alkalinity } \\
\left(\mathrm{mg} / \mathrm{L} \mathrm{CaCO}_{3}\right)\end{array}$ & $45.7(24.7 / 52.2)$ & $42.5(39.4 / 46.3)$ & $41.4(38.1 / 46.2)$ & $40.0(36.7 / 46.1)$ & $82.0(57.8 / 104)$ & $39.7(36.2 / 53.1)$ \\
\hline $\begin{array}{l}\text { Acidity }(\mathrm{mg} / \mathrm{L} \\
\left.\mathrm{CaCO}_{3}\right)\end{array}$ & $-21.8(-26.0 /-16.0)$ & $-19.8(-24.0 /-15.0)$ & $-19.5(-22.0 /-17.0)$ & $-19.4(-23 /-14)$ & $-81.1(-103 /-52)$ & $-22.7(-41 /-11.0)$ \\
\hline $\mathrm{Al}$, total $(\mathrm{mg} / \mathrm{L})$ & $1.15(0.20 / 2.60)$ & $0.90(0.70 / 1.90)$ & $0.90(0.60 / 1.90)$ & $0.90(0.60 / 1.70)$ & $<0.10(<0.10 / 0.30)$ & $0.90(0.20 / 1.60)$ \\
\hline $\begin{array}{l}\mathrm{Al}, \text { dissolved (mg/ } \\
\mathrm{L})\end{array}$ & $0.15(<0.10 / 1.20)$ & $<0.10(<0.1 / 0.20)$ & $<0.10(<0.10 / 0.10)$ & $<0.10(<0.10 / 0.10)$ & $<0.10(<0.10 / 0.20)$ & $<0.10(<0.10 / 0.10)$ \\
\hline $\mathrm{Ca}$, total $(\mathrm{mg} / \mathrm{L})$ & $38.1(33.6 / 42.7)$ & $38.8(33.4 / 47.6)$ & $39(33.4 / 44.5)$ & $38.8(35.2 / 41.7)$ & $63.3(51.1 / 71.4)$ & $40.2(35.1 / 50.1)$ \\
\hline $\begin{array}{l}\mathrm{Ca}, \text { dissolved } \\
(\mathrm{mg} / \mathrm{L})\end{array}$ & $37.6(34.6 / 40.5)$ & $38.6(34.4 / 40.9)$ & $38.2(35.0 / 40.9)$ & $38.0(34.8 / 41.8)$ & $59.7(51.4 / 75.3)$ & $38.5(35.3 / 53.0)$ \\
\hline $\mathrm{Fe}$, total $(\mathrm{mg} / \mathrm{L})$ & $11.30(5.94 / 17.9)$ & $10.40(5.72 / 17.8)$ & $9.98(5.71 / 15.9)$ & $9.31(5.35 / 13.9)$ & $0.11(0.02 / 1.20)$ & $8.75(3.30 / 14.2)$ \\
\hline $\begin{array}{l}\text { Fe, dissolved } \\
(\mathrm{mg} / \mathrm{L})\end{array}$ & $11.30(4.82 / 14.2)$ & $9.91(4.08 / 13.7)$ & $8.81(3.94 / 12.4)$ & $8.02(3.79 / 12.2)$ & $0.06(0.02 / 1.02)$ & $7.52(2.21 / 10.2)$ \\
\hline $\mathrm{Mg}$, total $(\mathrm{mg} / \mathrm{L})$ & $33.2(29.5 / 39.4)$ & $33.9(29.0 / 43.8)$ & $34.6(28.9 / 42.3)$ & $34.1(31.5 / 41.6)$ & $32.5(22.4 / 42.9)$ & $34.3(31.1 / 42.9)$ \\
\hline$\underset{(\mathrm{mg} / \mathrm{L})}{\mathrm{Mg}, \text { dissolved }}$ & $33.5(30.1 / 37.4)$ & $33.5(30.2 / 36.7)$ & $33.8(30.9 / 36.6)$ & $32.9(31.0 / 38.2)$ & $31.2(24.1 / 36.2)$ & $33.3(30.5 / 37.3)$ \\
\hline Mn, total $(\mathrm{mg} / \mathrm{L})$ & $2.15(1.82 / 2.63)$ & $2.16(1.81 / 2.94)$ & $2.20(1.76 / 2.70)$ & $2.16(1.84 / 2.67)$ & $0.36(0.09 / 1.47)$ & $1.98(1.69 / 2.66)$ \\
\hline $\begin{array}{l}\text { Mn, dissolved } \\
(\mathrm{mg} / \mathrm{L})\end{array}$ & $2.10(1.84 / 2.65)$ & $2.12(1.73 / 2.66)$ & $2.11(1.78 / 2.67)$ & $2.10(1.82 / 2.64)$ & $0.38(0.08 / 1.42)$ & $1.97(1.63 / 2.63)$ \\
\hline $\mathrm{Ni}$, total $(\mathrm{mg} / \mathrm{L})$ & $0.08(0.07 / 0.10)$ & $0.07(0.07 / 0.10)$ & $0.08(0.07 / 0.10)$ & $0.08(0.07 / 0.10)$ & $0.02(0.01 / 0.07)$ & $0.07(0.07 / 0.10)$ \\
\hline $\begin{array}{l}\mathrm{Ni}, \text { dissolved } \\
(\mathrm{mg} / \mathrm{L})\end{array}$ & $0.07(0.07 / 0.09)$ & $0.07(0.07 / 0.09)$ & $0.08(0.07 / 0.09)$ & $0.07(0.07 / 0.09)$ & $0.02(0.01 / 0.07)$ & $0.07(0.07 / 0.08)$ \\
\hline $\mathrm{K}$, total $(\mathrm{mg} / \mathrm{L})$ & $1.25(0.8 / 1.5)$ & $1.3(0.8 / 1.9)$ & $1.3(0.8 / 1.7)$ & $1.4(0.8 / 1.7)$ & $1.45(0.9 / 2.4)$ & $1.4(0.8 / 1.8)$ \\
\hline $\mathrm{K}$, dissolved & $1.3(0.9 / 1.5)$ & $1.3(0.9 / 1.7)$ & $1.3(0.9 / 1.7)$ & $1.3(0.9 / 2.2)$ & $1.4(1.0 / 2.4)$ & $1.35(0.9 / 1.8)$ \\
\hline $\mathrm{Na}$, total $(\mathrm{mg} / \mathrm{L})$ & $7.15(5.6 / 8.8)$ & $6.9(6.3 / 10.3)$ & $6.85(6.0 / 9.3)$ & 7.1(5.9/9.2) & $7.0(5.7 / 9.5)$ & $7.25(5.8 / 9.9)$ \\
\hline $\begin{array}{l}\mathrm{Na}, \text { dissolved } \\
(\mathrm{mg} / \mathrm{L})\end{array}$ & 7.3(6.3/7.9) & $7.0(6.1 / 8.7)$ & $7.25(6.0 / 8.5)$ & $7.1(6.0 / 9.5)$ & $6.85(6.1 / 8.3)$ & $7.2(6.4 / 8.7)$ \\
\hline $\mathrm{Zn}$, total $(\mathrm{mg} / \mathrm{L})$ & $0.12(0.10 / 0.18)$ & $0.12(0.09 / 0.18)$ & $0.12(0.09 / 0.18)$ & $0.12(0.10 / 0.18)$ & $0.03(0.01 / 0.06)$ & $0.12(0.08 / 0.17)$ \\
\hline $\begin{array}{l}\mathrm{Zn}, \text { dissolved } \\
(\mathrm{mg} / \mathrm{L})\end{array}$ & $0.12(0.09 / 0.17)$ & $0.12(0.10 / 0.16)$ & $0.11(0.09 / 0.16)$ & $0.11(0.09 / 0.16)$ & $0.03(0.01 / 0.07)$ & $0.11(0.07 / 0.15)$ \\
\hline$\underset{(\mathrm{mg} / \mathrm{L})}{\mathrm{Cl}, \text { dissolved }}$ & $2.41(2.09 / 2.55)$ & $2.43(2.13 / 2.84)$ & $2.47(2.14 / 2.91)$ & $2.5(2.17 / 2.95)$ & $2.92(2.12 / 4.25)$ & $2.51(2.16 / 3.0)$ \\
\hline $\begin{array}{l}\mathrm{SO}_{4}, \text { dissolved } \\
(\mathrm{mg} / \mathrm{L})\end{array}$ & $212(196 / 230)$ & $210(195 / 231)$ & $210(196 / 236)$ & $208(195 / 246)$ & $196(181 / 244)$ & $208(194 / 229)$ \\
\hline $\log \left(\mathrm{pCO}_{2}, \mathrm{~atm}\right)$ & $-1.6(-1.8 /-1.3)$ & $-1.8(-2.0 /-1.5)$ & $-1.8(-2.2 /-1.5)$ & $-1.9(-2.3 /-1.5)$ & $-2.0(-2.3 /-1.4)$ & $-2.1(-2.4 /-1.7)$ \\
\hline $\log \left(\mathrm{pO}_{2}, \mathrm{~atm}\right)$ & $-40.0(-48.0 /-23.0)$ & $-38.6(-46.0 /-23.0)$ & $-38.0(-45.0 /-24.0)$ & $-35.9(-45.0 /-24.0)$ & $-31.6(-45.5 /-21.7)$ & $-38.2(-47.0 /-28.0)$ \\
\hline SI Calcite & $-2.2(-2.5 /-2.0)$ & $-1.9(-2.3 /-1.8)$ & $-1.9(-2.2 /-1.7)$ & $-1.8(-2.3 /-1.6)$ & $-1.2(-1.5 /-0.6)$ & $-1.7(-2.0 /-1.5)$ \\
\hline SI Gypsum & $-1.6(-1.6 /-1.5)$ & $-1.6(-1.6 /-1.5)$ & $-1.6(-1.6 /-1.5)$ & $-1.6(-1.6 /-1.5)$ & $-1.4(-1.4 /-1.3)$ & $-1.5(-1.6 /-1.4)$ \\
\hline $\mathrm{SI} \mathrm{Al}(\mathrm{OH})_{3}$ am & $-0.1(-0.4 / 1.0)$ & $0.2(0.0 / 0.3)$ & $-0.1(-0.1 /-0.1)$ & $-0.1(-0.1 /-0.1)$ & $0.1(-0.1 / 0.3)$ & $-0.2(-0.2 /-0.2)$ \\
\hline SI Siderite & $-0.6(-3.3 /-0.3)$ & $-0.4(-3.5 /-0.2)$ & $-0.4(-3.3 /-0.1)$ & $-0.5(-3.3 /-0.3)$ & $-2.9(-6.0 /-0.9)$ & $-0.6(-2.3 / 0.0)$ \\
\hline SI Ferrihydrite & $2.2(-0.4 / 3.4)$ & $2.8(0.4 / 3.9)$ & $2.7(0.7 / 4.2)$ & $3.0(0.6 / 4.5)$ & $2.0(0.6 / 3.1)$ & $2.8(0.3 / 4.6)$ \\
\hline SI Rhodochrosite & $-0.9(-1.3 /-0.7)$ & $-0.7(-1.0 /-0.5)$ & $-0.7(-0.9 /-0.4)$ & $-0.6(-1.0 /-0.3)$ & $-0.9(-1.2 /-0.4)$ & $-0.5(-0.8 /-0.2)$ \\
\hline SI Manganite & $-5.6(-8.2 /-1.8)$ & $-4.9(-7.4 /-0.9)$ & $-5.1(-7.1 /-0.9)$ & $-4.6(-7.2 /-0.7)$ & $-3.4(-6.4 /-0.5)$ & $-4.7(-7.0 /-1.7)$ \\
\hline SI Pyrolusite & $-11.9(-16.0 /-4.0)$ & $-10.9(-15.0 /-3.1)$ & $-10.6(-14.0 /-3.4)$ & $-9.6(-14.0 /-3.3)$ & $-7.5(-13.9 /-2.6)$ & $-10.4(-14.0 /-5.3)$ \\
\hline
\end{tabular}

operation, especially during high-flow conditions in January-March 2006. Transport of sulfate, calcium, alkalinity, iron, manganese, and aluminum to the treatment system was positively correlated with flow; net acidity (negative values) was inversely correlated with flow. Except for iron, aluminum, and alkalinity, only a small fraction of the constituents in the influent AMD was attenuated within the oxidation pond and wetlands. Sulfate was transported conservatively through the treatment system (Fig. $5 \mathrm{~g}$ ), with average influent (Otto 235-m) and effluent (Otto 470-m) 

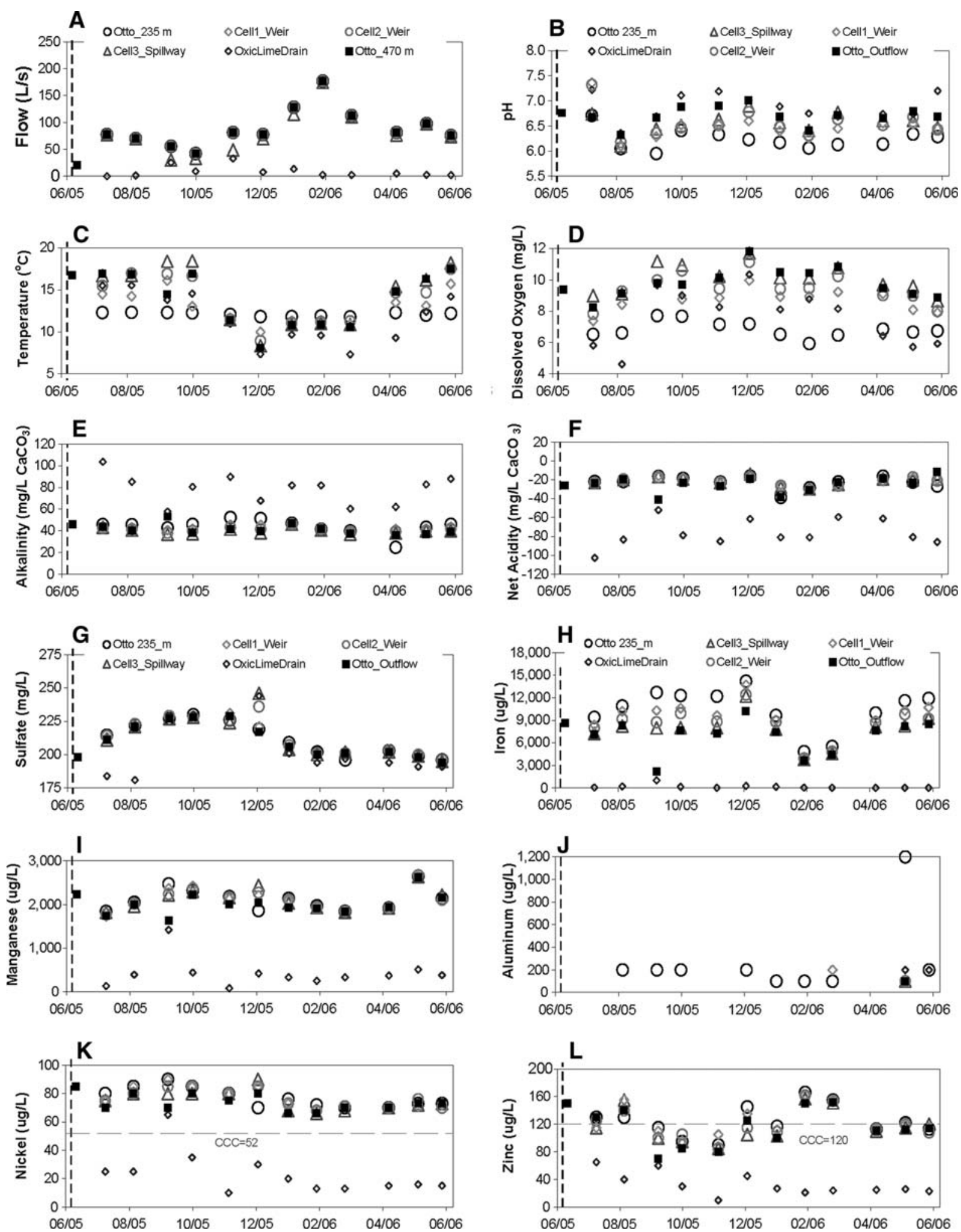

Fig. 5 Time-series plots of the quality of water at sequential monitoring points through the Otto Discharge Treatment system (June 2005-June 2006). a Flow rate; b pH; c temperature; d dissolved oxygen; e alkalinity; $\mathbf{f}$ net acidity; $\mathbf{g}$ sulfate; $\mathbf{h}$ dissolved iron; i dissolved manganese; $\mathbf{j}$ dissolved aluminum; $\mathbf{k}$ dissolved nickel; 1 dissolved zinc. Data for Otto 235_m and Otto 470_m represent

influent and effluent from the treatment system and for cells 1,2 , and 3 correspond with the effluent from the oxidation pond, first wetland, and second wetland, respectively. Values below detection limits were plotted as negative (below axis). CCC is criteria continuous concentration for freshwater organisms (U.S. Environmental Protection Agency 2002) 
loadings of 592 and 590 t/year, respectively. Chloride, sodium, magnesium, and potassium also were not affected by the aerobic treatment (Table 3 ). In contrast, $9.2 \mathrm{t} /$ year of dissolved iron, manganese, and aluminum, equivalent to acidity of $17.3 \mathrm{t}$ /year (Eq. 4), were removed at a rate of $27.1 \%$ per year. Iron accounted for the majority of metals removal in the treatment system, with average influent and effluent loadings of 27.9 and $19.0 \mathrm{t}$ /year, respectively. Given a total area of $6,670 \mathrm{~m}^{2}$ for the oxidation pond and wetlands combined (Fig. 2), the areal removal rate for iron was only $3.7 \mathrm{~g} / \mathrm{m}^{2} /$ day. The average alkalinity loading decreased only by $6.5 \mathrm{t}$ /year instead of decreasing at a rate of $17.3 \mathrm{t} /$ year equal to the metals acidity removed, and the net-acidity loading decreased by 11.0 t/year instead of remaining constant. The lower than expected consumption rate for alkalinity and the negative values for net acidity transport through the system indicate that alkalinity consumption (acidity neutralization) associated with iron removal was partially offset by alkalinity production. An average of $10.3 \mathrm{t}$ /year of calcium as $\mathrm{CaCO}_{3}$ was added by the treatment system, which is comparable in magnitude to the $11.0 \mathrm{t} / \mathrm{year}$ decrease in net acidity (alkalinity added).

Dissolution of limestone coupled with the precipitation of iron and aluminum are likely explanations for the changes in loadings of calcium, alkalinity, and net acidity within the treatment system. Positive values for the saturation index of ferrihydrite $\left(\mathrm{Fe}(\mathrm{OH})_{3}\right)$ and amorphous $\mathrm{Al}(\mathrm{OH})_{3}($ Table 3$)$ are consistent with the potential precipitation of $\mathrm{Fe}(\mathrm{OH})_{3}$ and $\mathrm{Al}(\mathrm{OH})_{3}$ within the treatment system. Negative values for the saturation index of various manganese minerals (rhodochrosite, manganite, pyrolusite) are consistent with the conservative transport of dissolved manganese through the treatment system. Negative values for the saturation index of calcite $\left(\mathrm{CaCO}_{3}\right)$ and gypsum $\left(\mathrm{CaSO}_{4} \cdot 2 \mathrm{H}_{2} \mathrm{O}\right)$ indicate that these minerals would not precipitate and, if present, could have dissolved, contributing calcium (Table 3). In addition to the oxic limestone drain, limestone rip rap was used to line spillways between treatment cells; limestone and gypsum also could have been present in mushroom compost used as planting substrate for the wetland cells. Dissolution of $\mathrm{CaCO}_{3}$ in limestone produces alkalinity; dissolution of gypsum produces sulfate but does not affect alkalinity. Small decreases in sulfate compared to increases in calcium concentrations and loadings indicate that gypsum was not an important source of calcium and/or that bacterial sulfate reduction was subordinate to limestone dissolution as a source of alkalinity.

The 9-37 h cumulative detention times (travel times) through the treatment system were consistent with the aeration-experiment conditions. However, in contrast with 80-100\% removal of $\mathrm{Fe}^{2+}$ over similar elapsed times during the aeration experiment (Fig. 3a), the treatment system typically removed less than $35 \%$ of the influent iron (Figs. 4h, 5h). Although concentrations of dissolved $\mathrm{CO}_{2}$ decreased progressively within the treatment system, the $\mathrm{PCO}_{2}$ values for treated effluent remained elevated $\left(10^{-2.4}\right.$ to $10^{-1.7}$ atm) (Table 3). The elevated $\mathrm{PCO}_{2}$ maintained the $\mathrm{pH}$ within the wetland cells of the treatment system at values less than 7 (Fig. 5b) and, hence, slowed the rate of $\mathrm{Fe}^{2+}$ oxidation compared to the aeration experiment. Consequently, effluent exiting the second wetland (cell 3) contained elevated residual concentrations of dissolved and total iron. When mixed with more alkaline water in the oxic limestone drain, this residual dissolved iron rapidly oxidized and precipitated, clogging the drain.

\section{Discussion: Modeling of Iron Oxidation and Treatment System Performance}

\section{Simulation of Iron-Oxidation and Removal Rates}

The treatment system lacked continuous aeration that facilitated the exsolution of $\mathrm{CO}_{2}$ during the laboratory aeration experiment and, consequently, did not produce corresponding high $\mathrm{pH}$ values needed for rapid oxidation of $\mathrm{Fe}^{2+}$. Using the data for the laboratory aeration experiment (Fig. 3) and previously described rate equations for $\mathrm{Fe}^{2+}$ oxidation (Eqs. 5 and 6), kinetic oxidation models were developed to evaluate the effects of dissolved $\mathrm{CO}_{2}$ and $\mathrm{pH}$ on the oxidation rate (Fig. 6).

The kinetic oxidation models indicate a wide range of possible trends for dissolved iron removal (Fig. 6a). Assuming a constant $\mathrm{pH}$ of 6.0 or 6.5 for the $\mathrm{pH}$-dependent rate Eq. 5 of Stumm and Lee (1961) and Singer and Stumm (1970) yielded results for residual $\mathrm{Fe}$ (dashed curves in Fig. 6a) that were comparable in magnitude but did not match measured values for dissolved $\mathrm{Fe}$ (triangle symbols in Fig. 6a). The Williamson et al. (1992) rate model produced results comparable to the Singer and Stumm model for $\mathrm{pH}$ 6.5. Initial PHREEQC models using the same rate equations but considering variable $\mathrm{pH}$, solubility control of $\mathrm{Fe}^{3+}$ by $\mathrm{Fe}(\mathrm{OH})_{3}$, and solution equilibrium with atmospheric $\mathrm{O}_{2}$ and $\mathrm{CO}_{2}$ also produced unrealistic results (thin solid curves in Figs. 6a through 6d). Although equilibrium with atmospheric $\mathrm{O}_{2}$ was reasonable, the assumed equilibrium with atmospheric $\mathrm{CO}_{2} \quad\left(\mathrm{PCO}_{2}=10^{-3.5}\right.$ atm; $\mathrm{pCO}_{2}=3.5$ ) produced an instantaneous increase in $\mathrm{pH}$ to alkaline values and resulted in nearly instantaneous oxidation and removal of the iron. The assumptions of constant $\mathrm{pH}$ or $\mathrm{pH}$ in equilibrium with atmospheric $\mathrm{CO}_{2}$ were not supported with the data.

Because the observed values of $\mathrm{pH}$ increased asymptotically and were inversely correlated with the $\mathrm{PCO}_{2}$ (Fig. 3d, f), the PHREEQC models were refined by 

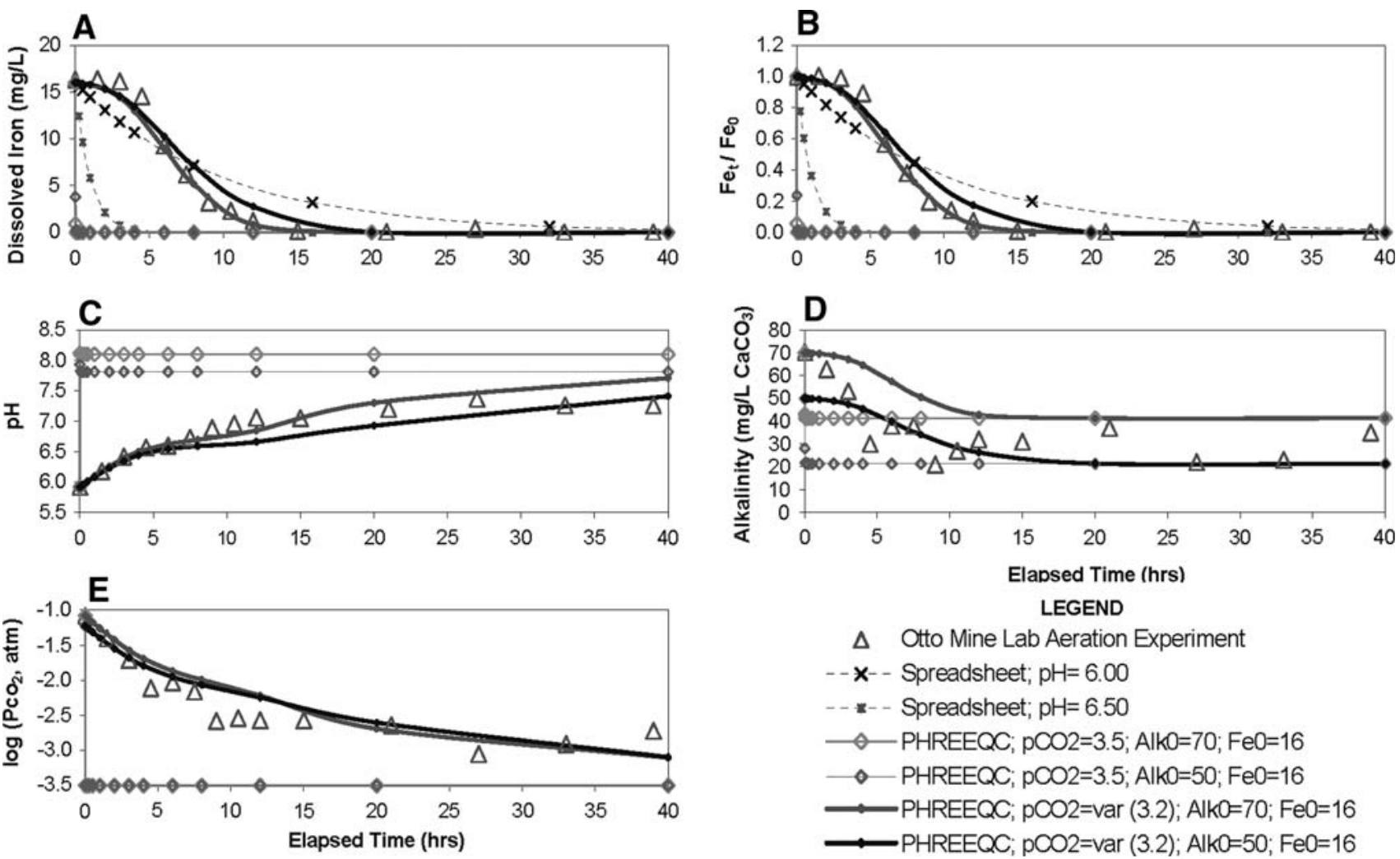

Fig. 6 Kinetic modeling results for laboratory aeration experiment on the Otto Discharge conducted December 3-7, 2001. a Iron concentration; $\mathbf{b}$ ratio of iron concentration in effluent $\left(\mathrm{Fe}_{\mathrm{t}}\right)$ to initial concentration in influent $\left(\mathrm{Fe}_{0}\right) ; \mathbf{c} \mathrm{pH} ; \mathbf{d}$ alkalinity; e $\mathrm{PCO}_{2}$. Measured values shown as triangle symbols. Model results shown as dashed curves for spreadsheet models that assume constant $\mathrm{pH}$ and solid

including a rate term to describe the asymptotic decreases in observed $\mathrm{PCO}_{2}$ with time. Equation 12 was rewritten and the derivative was expressed in terms of moles of dissolved $\mathrm{CO}_{2}$ (Appendix $\mathrm{A}$ in Electronic supplementary material). The refined models with variable $\mathrm{PCO}_{2}$ (thick solid curves in Fig. 6) yielded results that were consistent with the observed data for iron, $\mathrm{pH}$, alkalinity, and $\mathrm{PCO}_{2}$. As expected, the rate of iron removal varied as a function of $\mathrm{pH}$. Different results were obtained for initial alkalinities of 70 and $50 \mathrm{mg} / \mathrm{L}$ as $\mathrm{CaCO}_{3}$. Lower concentrations of initial alkalinity provided less buffering; $\mathrm{pH}$ values and associated iron-oxidation rates were lower.

\section{Treatment-System Performance}

The PHREEQC abiotic iron-oxidation rate models, coupled with the rate equation describing $\mathrm{PCO}_{2}$ evolution during the laboratory aeration experiment, yielded results that differed from observed influent and effluent data as a function of the cumulative detention time or traveltime through the treatment system (Fig. 7). The field rate of $\mathrm{Fe}^{2+}$

oxidation generally was slower than predicted by the rate models describing the laboratory conditions. The $\mathrm{pH}$ under field conditions increased slowly and rarely attained values approaching 7 (Fig. 7c) and the $\mathrm{PCO}_{2}$ values for treated effluent remained elevated $\left(10^{-2.4}\right.$ to $\left.10^{-1.7} \mathrm{~atm}\right)$ (Fig. 7e). The slow exsolution of $\mathrm{CO}_{2}$, low $\mathrm{pH}$, and slow rate of iron oxidation under field conditions reflect conditions far from equilibrium with the atmosphere.

In an attempt to improve the modeling results, the value for steady-state $\mathrm{PCO}_{2}$ and the starting values for the initial solution were changed to reflect typical field conditions (median values in Table 3). The initial concentration of $\mathrm{Fe}^{2+}$ was decreased from 16.4 to $12.0 \mathrm{mg} / \mathrm{L}$, initial alkalinity was decreased from 70 to $50 \mathrm{mg} / \mathrm{L}$, and steady-state minimum $\mathrm{PCO}_{2}$ was increased from $10^{-3.2}$ to $10^{-2.3} \mathrm{~atm}$. The results of these simulations (shown as dashed curves in Fig. 7) were more consistent with field observations but still indicated more extensive removal of iron than observed under field conditions.

The actual field conditions were more complex than indicated by the models. Plots of the observed monthly data and associated traveltimes for samples collected 

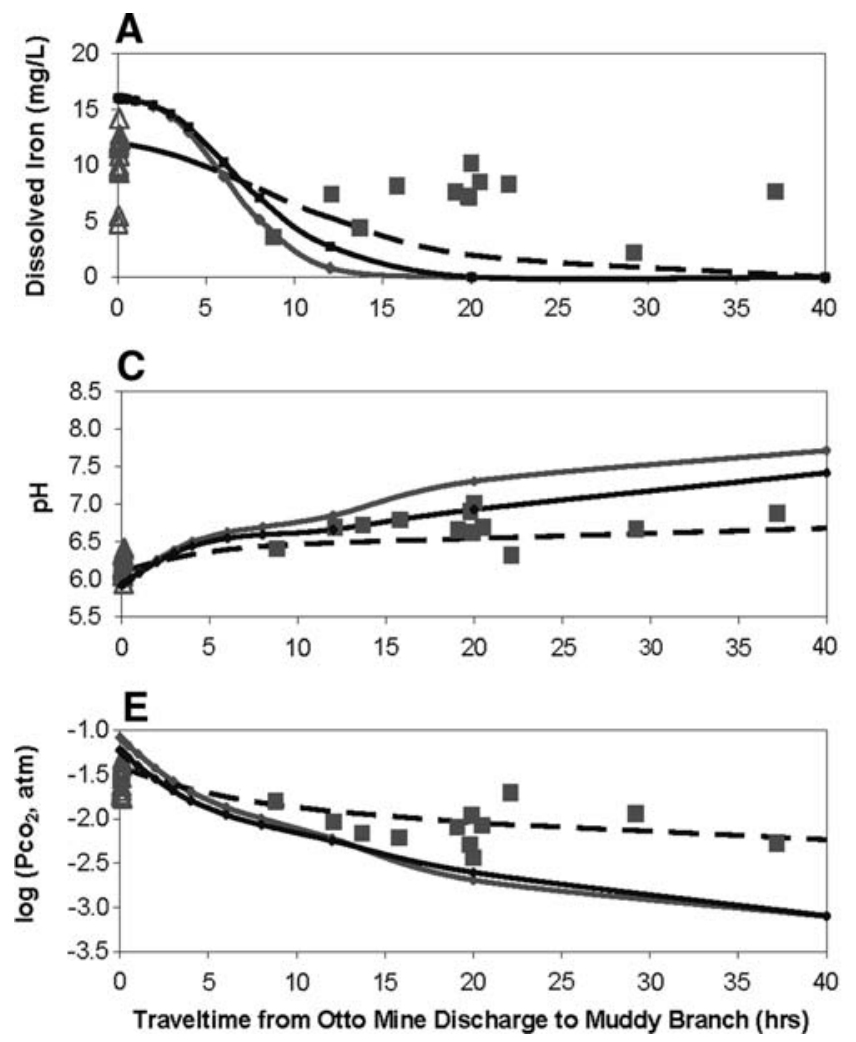

Fig. 7 Kinetic modeling results for influent (Otto 235-m) and effluent (Otto 470-m) from the Otto Discharge treatment system. a Iron concentration; $\mathbf{b}$ ratio of iron concentration in effluent $\left(\mathrm{Fe}_{t}\right)$ to initial concentration in influent $\left(\mathrm{Fe}_{0}\right)$; c pH; d alkalinity; e $\mathrm{PCO}_{2}$. Measured values shown as triangle symbols for influent and square symbols for effluent. Model results shown as solid curves for PHREEQC models based on aeration test results and dashed curves

within the treatment system indicated widely different trends compared to the model results (Fig. 8). The field data, as plotted in Fig. 8 showing connected symbols for consecutive downflow samples on a given date, indicate progressive changes in chemistry from the inflow (Otto 235-m), oxidation pond, first wetland, second wetland, and then outflow (Otto 470-m). However, the treatment efficiency was not consistent for each cell or for a given cell on different dates. Despite detention times of 7.6-31.9 $\mathrm{h}$ in the first cell (Table 3), the water quality changed little within this planned "oxidation pond." In contrast, detention times were $3.0 \mathrm{~h}$ or less in the two shallow wetlands, but rates of iron removal, $\mathrm{pH}$ increase, and $\mathrm{PCO}_{2}$ reduction were faster and, hence, chemical reactions were more efficient in these cells. Gas exchange with the atmosphere apparently is more efficient in the shallow cells compared to the deeper oxidation pond. Accounting for the time lag within the first pond, the rates of reactions within the two wetlands and in the overflow ditch above the last sample site (Otto 470-m) generally were consistent with modeled
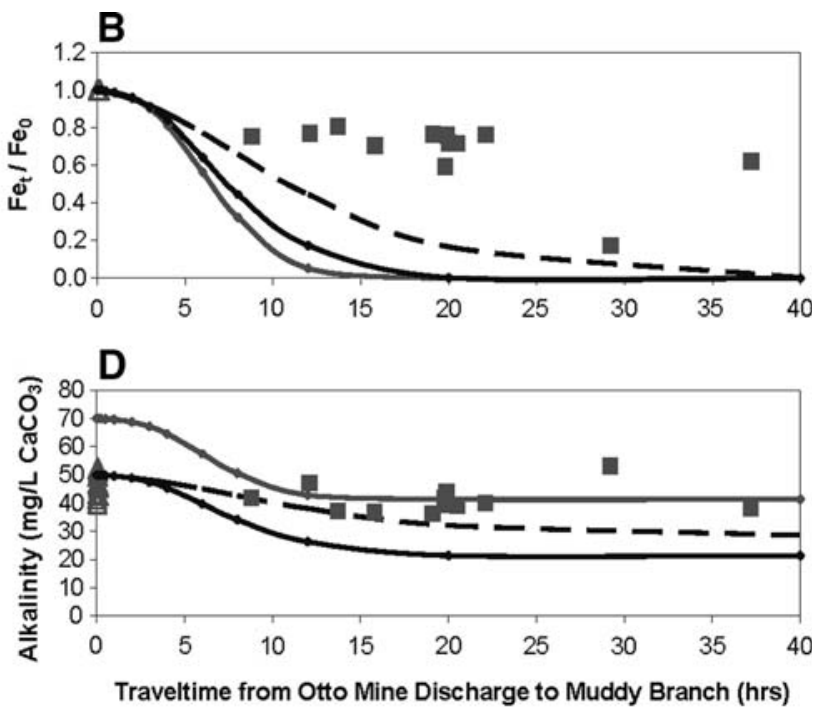

LEGEND

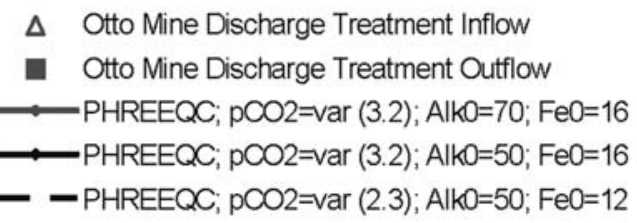

for PHREEQC models adjusted for lower median iron concentration of influent and higher median $\mathrm{PCO}_{2}$ of effluent for treatment system. The PHREEQC models consider initial iron concentrations of 16.0 or $12.0 \mathrm{mg} / \mathrm{L}$, initial alkalinities of 70 or $50 \mathrm{mg} / \mathrm{L}$, and variable $\mathrm{PCO}_{2}$ computed with Eq. 11 where $k$ is $0.0906 \mathrm{~h}^{-1}, C_{0}$ is -1.08 , and $C_{\mathrm{S}}$ is -3.2 (solid curves) or -2.3 (dashed curve)

rates. Although it is beyond the scope of this paper to establish design criteria for treatment systems, the surface area to volume ratio of aerobic ponds or wetlands could be an important criterion for degassing of $\mathrm{CO}_{2}$ and warrants further evaluation.

The relation between the traveltime and the corresponding measured $\mathrm{pH}$ and rates of iron removal within the wetlands have implications for the optimization of the Otto treatment system and the design of other AMD treatment systems. The oxidation models described above enabled the evaluation of these relations. Specifically, the differences between the two PHREEQC models (solid and dashed curves) and the field data (Fig. 8) indicate that excess dissolved $\mathrm{CO}_{2}$ can maintain the $\mathrm{pH}$ to less than 7; improved iron removal can be expected for conditions where $\mathrm{pH}$ is greater than 7 . In a study of passive minedrainage treatment systems, Kirby et al. (1999) found that for AMD with $\mathrm{pH}$ between 5 and 6.4, Fe oxidation was positively correlated with $\mathrm{pH}$ and that treatment efficiency could be improved by increasing the $\mathrm{pH}$; oxidation 

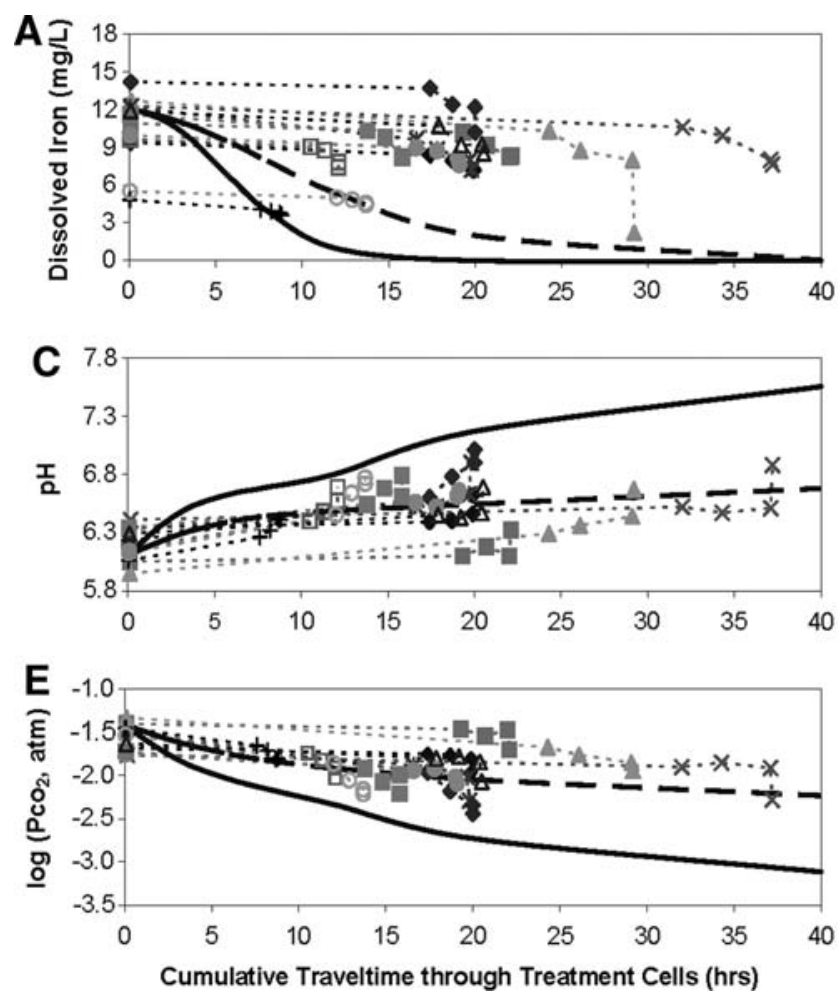

Fig. 8 Kinetic modeling results and observed monthly data on water quality and cumulative traveltimes at points through the Otto Discharge treatment system. a Iron concentration; b ratio of iron concentration in effluent $\left(\mathrm{Fe}_{\mathrm{t}}\right)$ to initial concentration in influent $\left(\mathrm{Fe}_{0}\right)$;

appeared to be primarily abiotic. Net-alkaline AMD commonly has excess dissolved $\mathrm{CO}_{2}$, which depresses the $\mathrm{pH}$; aggressive aeration of AMD can facilitate $\mathrm{CO}_{2}$ exsolution and promote $\mathrm{pH}$ increases needed to accelerate $\mathrm{Fe}^{2+}$ oxidation. Aerobic wetlands or ponds to treat netalkaline AMD could include aeration components such as splash features, windmills, or hydraulic aeration to promote oxygenation, exsolution of $\mathrm{CO}_{2}$, and increase of $\mathrm{pH}$ needed to sustain high rates of abiotic $\mathrm{Fe}^{2+}$ oxidation. The treatment system for the Otto Discharge could incorporate various aeration features to improve its efficiency. Furthermore, vertical panels could be installed within the oxidation pond to divide the pond into multiple cells and prevent short-circuiting. Once the iron-removal rate is improved, the oxic limestone drain could be reconstructed to include a flushing pipe network for removal of accumulated $\mathrm{Fe}(\mathrm{OH})_{3}$ and other solids. Without flushing capability, the oxic limestone drain rapidly clogged; however, it was more effective than the oxidation pond or wetlands for removal of dissolved iron, manganese, nickel, and zinc, and it increased alkalinity and maintained lower temperatures than the effluent from the aerobic wetlands. During hot summer months, water
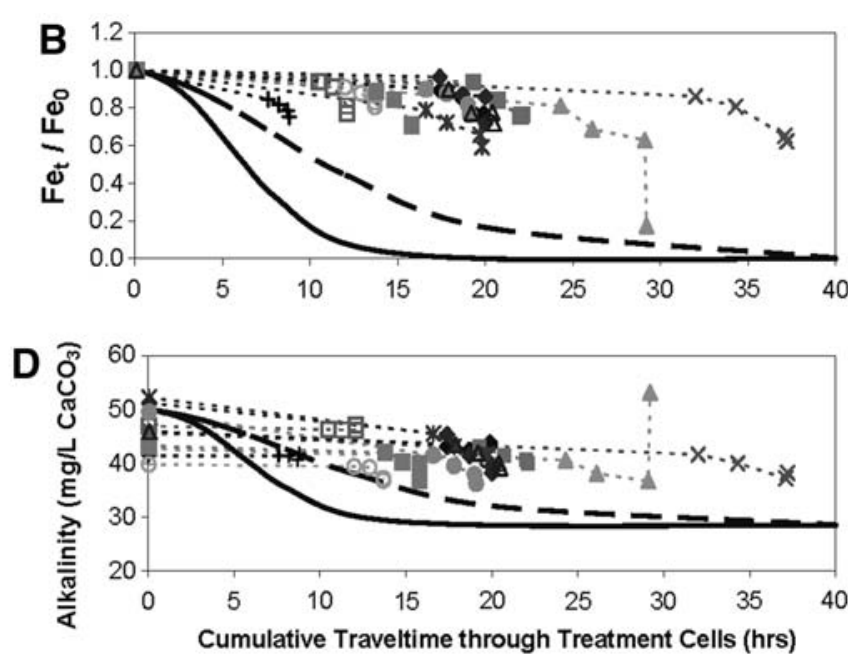

$$
\begin{aligned}
& \text { LEGEND }
\end{aligned}
$$

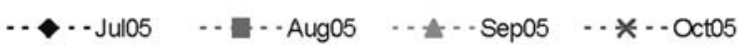

$$
\begin{aligned}
& \text {-**Nov05 } \cdots * \text { - Dec05 } \cdots \square \cdots \text { - Jan06 } \cdots+\cdots \text { Feb06 }
\end{aligned}
$$

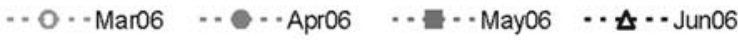

c $\mathrm{pH}$; d alkalinity; e $\mathrm{PCO}_{2}$. The PHREEQC models consider initial iron concentration of $12.0 \mathrm{mg} / \mathrm{L}$, initial alkalinity of $50 \mathrm{mg} / \mathrm{L}$, and variable $\mathrm{PCO}_{2}$ computed with Eq. 11 where $k$ is $0.0906 \mathrm{~h}^{-1}, C_{0}$ is -1.08 , and $C_{\mathrm{S}}$ is -3.2 (solid curve) or -2.3 (dashed curve)

exiting the wetlands directly to the stream could be too warm for cold-water fish in Muddy Branch.

\section{Summary and Conclusions}

The Otto Discharge is one of the largest AMD sources in the upper Schuylkill River Basin in eastern Pennsylvania. Although near neutral and net alkaline, the untreated discharge is suboxic and has elevated concentrations of dissolved iron where it emerges from a flooded anthracite mine tunnel. The discharge is a major source of base flow to Muddy Branch and the West Branch Schuylkill River. Despite the loading of iron and other metals from the Otto Discharge, Muddy Branch and other downstream waters support several species of cold-water fish, including brook trout.

A laboratory aeration experiment in 2001 demonstrated that continuous bubbling of air accelerated the oxidation and precipitation of iron while $\mathrm{pH}$ remained near neutral. The net-alkaline character and laboratory test results supported a remediation strategy using aerobic wetlands. The conceptual system, ideally, would consist of an oxidation 
pond with aeration to facilitate iron oxidation, planted wetland(s) to facilitate removal of suspended iron oxide particles, and a flushable underground limestone bed to promote the removal of manganese and trace metals and to mitigate temperature effects associated with prolonged exposure of the water in shallow wetlands.

The as-built treatment system incorporated most features of the conceptual design but excluded the hydraulic aeration at the inflow and the flushing pipes from the oxic limestone drain. The system began treating water in June 2005. Less than $35 \%$ of the influent iron loading and less than $1 \%$ of the manganese, nickel, and zinc loadings were removed within the oxidation pond and two wetlands. In contrast, the oxic limestone drain at the outflow from the second wetland effectively removed iron, manganese, nickel, and zinc and moderated the temperature of the effluent. However, the oxic limestone drain became clogged within the first month of operation. Thereafter, most of the treated effluent discharged from the second wetland to Muddy Branch. Monitoring of Muddy Branch above and below the Otto Discharge showed that the wetlands treatment promoted increased downstream water temperatures during summer but did not adversely affect the cold-water fish populations during the study. Monitoring of the treatment system indicated average removal rates of $9.2 \mathrm{t} / \mathrm{year}$ for iron, manganese, and aluminum, equating to $27.1 \%$ of the influent metals loading. The average areal removal rate for iron within the oxidation pond and wetlands was only $3.7 \mathrm{~g} / \mathrm{m}^{2} /$ day. This removal rate is much lower than expected based on results of the laboratory aeration experiment and median detention times of $19.9 \mathrm{~h}$ within the treatment system. During the first $12 \mathrm{~h}$ of the laboratory aeration experiment, nearly all of the dissolved iron was precipitated; the initial iron concentration of $16.4 \mathrm{mg} / \mathrm{L}$ decreased to less than $0.5 \mathrm{mg} / \mathrm{L}$.

As demonstrated in this paper, aeration experiments and PHREEQC modeling of iron-oxidation rates can be useful in indicating potential performance of aerobic wetlands for treatment of net-alkaline AMD. In the case of the Otto Discharge, the performance of the as-built treatment system could be evaluated relative to the laboratory aeration experiment that demonstrated more favorable conditions for iron removal. The aeration experiment maintained saturation with dissolved $\mathrm{O}_{2}$ and promoted more rapid oxidation of dissolved iron than observed in the treatment system. Nevertheless, kinetic models of iron oxidation simulated with PHREEQC showed that dissolved $\mathrm{CO}_{2}$ was a critical variable affecting the $\mathrm{pH}$ and associated iron-oxidation rates. Despite aggressive bubbling of air through the AMD during the aeration experiment and prolonged exposure of the AMD to the atmosphere in the wetlands, dissolved $\mathrm{CO}_{2}$ remained elevated compared to atmospheric equilibrium $\mathrm{PCO}_{2}$ of $10^{-3.5}$ atm. Rates of oxidation were slowed by elevated $\mathrm{CO}_{2}$ that maintained low $\mathrm{pH}$ values compared to atmospheric equilibrium. Simulations of iron-oxidation rates were improved by incorporating an empirical equation describing the asymptotic exsolution of $\mathrm{CO}_{2}$ to steady-state $\mathrm{PCO}_{2}$ of $10^{-3.1}$ atm for the laboratory aeration experiment and $10^{-2.3}$ atm for field conditions.

Generally, the goal of AMD treatment is to restore aquatic quality in affected watersheds. Corresponding AMD treatment strategies need to identify and solve sitespecific problems, such as acid neutralization and/or metals removal, without creating other problems. For example, aerobic wetlands can be effective for removing iron from AMD; however, environmentally significant concentrations of manganese and toxic trace metals such as nickel and zinc may persist in treated effluent, and the treated effluent may become too warm to support fish during summer. The performance of the Otto Discharge treatment system and, possibly, other aerobic wetlands for removal of iron from net-alkaline AMD could be improved by aggressive, continuous aeration in an early stage to decrease $\mathrm{PCO}_{2}$, increase $\mathrm{pH}$, and accelerate iron oxidation. Furthermore, the routing of treated effluent from wetlands to underground, rock-filled drains could promote the removal of manganese and trace metals and moderate the temperature of treated effluent. Limestone placed in such beds has added potential to produce alkalinity, but void space can become clogged with $\mathrm{Fe}(\mathrm{OH})_{3}$. Improved designs and their implementation would be needed to enhance iron removal within constructed wetlands and to minimize clogging and other maintenance problems associated with $\mathrm{Fe}(\mathrm{OH})_{3}$ accumulation within limestone beds. Sustained monitoring of the flow, water quality, and aquatic ecology at AMD treatment sites and associated streams would be needed to produce data on the long-term performance and environmental effects of the treatment system(s).

Acknowledgments This project was conducted by the U.S. Geological Survey (USGS) in cooperation with the Schuylkill Headwaters Association, Inc. (SHA) and the Pennsylvania Department of Environmental Protection (PaDEP). The author gratefully acknowledges assistance from numerous individuals. Clayton Bubeck and Christine Haldeman of Rettew Associates developed and shared the construction details for the treatment system. Monitoring assistance was provided by Suzanne Ward, Emily Eggler, Adrian Biscontini, Michael Bilger, and Robin Brightbill of the USGS and Thomas Davidock of the Schuylkill Conservation District. Karl Schroeder of the U.S. Department of Energy and Carl Kirby of Bucknell University (BU) contributed analytical services and technical advice, respectively, for the aeration experiment. David Parkhurst of USGS helped with coding of the kinetics equations to simulate iron oxidation and carbon dioxide exsolution in the PHREEQC models. The manuscript benefited from reviews by Kevin Breen and David Parkhurst of USGS and Carl Kirby of BU. 


\section{References}

Ackman T, Kleinmann RLP (1985) In-line aeration and treatment of acid mine drainage - performance and preliminary design criteria. US Bur Mines Inf Circular 9027:53-61

American Public Health Association (1998a) Acidity (2310)/titration method. In: Clesceri LS, Greenberg AE, Eaton AD (eds) Standard methods for the examination of water and wastewater, 20th edn. American Public Health Assoc, Washington, pp 2.24-2.26

American Public Health Association (1998b) Alkalinity (2320)/ titration method. In: Clesceri LS, Greenberg AE, Eaton AD (eds) Standard methods for the examination of water and wastewater, 20th edn. American Public Health Assoc, Washington, pp 2.262.29

Ball JW, Nordstrom DK (1991) User's manual for WATEQ4F with revised data base. US Geol Surv Open-File Rep 91-183, 189 pp (http://wwwbrr.cr.usgs.gov/projects/GWC_chemtherm/pubs/ wq4fdoc.pdf)

Barbour MT, Gerritsen J, Snyder BD, Stribling JB (1999) Rapid bioassessment protocols for use in streams and wadeable riversperiphyton, benthic macroinvertebrates, and fish, 2nd edn. US Environmental Protection Agency EPA 841-B-99-002, 11 chapters, 4 appendices (http://www.epa.gov/OWOW/monitoring/ techmon.html)

Berg TM, Edmunds WE, Geyer AR, Glover AD, Hoskins DM, MacLachlan DB, Root SI, Sevon WD, Socolow AA (comps) (1980) Geologic map of Pennsylvania. Pa Geol Surv, 4th edit, Map \# 1, scale 1:2,500,000, 3 sheets

Butler RL, Cooper EL, Crawford JK, Hales DC, Kimmel WG, Wagner CC (1973) Fish and food organisms in acid mine waters of Pennsylvania. U.S. Environmental Protection Agency EPAR3-73-032, $158 \mathrm{pp}$

Chikotas B, Kaufman M (2002) Muddy Branch (603A) Fisheries Management Report. Pennsylvania Fish and Boat Commission, Bureau of Fisheries, $12 \mathrm{pp}$

Commonwealth of Pennsylvania (2002) Chapter 93. Water Quality Standards. Pennsylvania Code, Title 25. Environmental Protection. Commonwealth of Pennsylvania, Harrisburg, pp 93.193.226

Coston JA, Fuller CC, Davis JA (1995) $\mathrm{Pb}^{2+}$ and $\mathrm{Zn}^{2+}$ adsorption by a natural aluminum- and iron-bearing surface coating on an aquifer sand. Geochim Cosmochim Acta 59:3535-3547

Cravotta CA III (2007), Dissolved metals and associated constituents in abandoned coal-mine discharges, Pennsylvania, USA-1. Constituent concentrations and correlations. Appl Geochem (in press)

Cravotta CA, III, Brady KBC, Rose AW, Douds JB (1999) Frequency distribution of the $\mathrm{pH}$ of coal-mine drainage in Pennsylvania. In: Morganwalp DW, Buxton H (eds) Proceedings of the technical meeting, US Geological Survey Toxic Substances Hydrology Program, US Geol Surv Wat Resour Inv Rep 99-4018A, pp 313324

Cravotta CA III, Trahan MK (1999) Limestone drains to increase $\mathrm{pH}$ and remove dissolved metals from acidic mine drainage. Appl Geochem 14:581-606

Cravotta CA III, Watzlaf GR (2002) Design and performance of limestone drains to increase $\mathrm{pH}$ and remove dissolved metals from acidic mine drainage. In: Naftz DL, Morrison SJ, Fuller $\mathrm{CC}$, Davis JA (eds) Handbook of groundwater remediation using permeable reactive barriers-applications to radionuclides, trace metals, and nutrients. Academic, San Diego, pp 19-66

Crock JG, Arbogast BF, Lamothe PJ (1999) Laboratory methods for the analysis of environmental samples. In: Plumlee GS, Logsdon MJ (eds) The environmental geochemistry of mineral deposits-Part A. Processes, techniques, and health issues, Soc of Economic Geologists, Reviews in Economic Geology, 6A, pp 265-287
Dempsey BA, Roscoe HC, Ames R, Hedin R, Byong-Hun J (2001) Ferrous oxidation chemistry in passive abiotic systems for treatment of mine drainage. Geochem Explor Environ Anal $1: 81-88$

Dietz JM, Dempsey BA (2002) Innovative treatment of alkaline mine drainage using recirculated iron oxides in a complete mix reactor. In: Proceedings of National Meeting of the American Soc of Mining and Reclamation, pp 496-516

Earle J, Callaghan T (1998) Effects of mine drainage on aquatic life, water uses, and man-made structures. In: Brady KBC, Smith MW, Schueck JH (eds) The prediction and prevention of acid drainage from surface coal mines in Pennsylvania, Pennsylvania Dept of Environmental Protection, Harrisburg, 5600-BKDEP2256, pp 4.1-4.10

Eggleston JR, Kehn TM, Wood GH Jr (1999) Anthracite. In: Schultz CH (ed) The geology of Pennsylvania. Pa Geol Surv, 4th series, Special Publ \#1, pp 458-469

Fishman MJ, Friedman LC (eds) (1989) Methods for determination of inorganic substances in water and fluvial sediments. US Geol Surv Tech Wat Res Inv 5: A1, 545 pp

Growitz DJ, Reed LA, Beard MM (1985) Reconnaissance of mine drainage in the coal fields of eastern Pennsylvania. US Geol Surv Wat Resour Inv Rep 83-4274, 54 pp

Hedin RS, Nairn RW, Kleinmann RLP (1994) Passive treatment of coal mine drainage. US Bur Mines Information Circular IC 9389, 35 pp

Herlihy AT, Kaufmann PR, Mitch ME, Brown DD (1990) Regional estimates of acid mine drainage impact on streams in the midAtlantic and southeastern United States. Water Air Soil Pollut 50:91-107

Hyman DM, Watzlaf GR (1997) Metals and other components of coal mine drainage as related to aquatic life standards. In: Proceedings of 1997 National Meeting of the American Soc for Surface Mining and Reclamation, pp 531-545

Jageman TC, Yokley RA, Heunisch HE (1988) The use of preaeration to reduce the cost of neutralizing acid mine drainage. US Bur Mines Information Circular IC 9183, p 131-135

Kairies CL, Capo RC, Watzlaf GR (2005) Chemical and physical properties of iron hydroxide precipitates associated with passively treated coal mine drainage in the Bituminous Region of Pennsylvania and Maryland. Appl Geochem 20:1445-1460

Kirby CS, Cravotta CA III (2005a) Net alkalinity and net acidity $1-$ Theoretical considerations. Appl Geochem 20:1920-1940

Kirby CS, Cravotta CA III (2005b) Net alkalinity and net acidity 2Practical considerations. Appl Geochem 20:1941-1964

Kirby CS, Thomas HM, Southam G, Donald R (1999) Relative contributions of abiotic and biological factors in $\mathrm{Fe}(\mathrm{II})$ oxidation in mine drainage. Appl Geochem 14:511-530

Kooner ZS (1993) Comparative study of adsorption behavior of copper, lead, and zinc onto goethite in aqueous systems. Environ Geol 21:342-250

L. Robert Kimball \& Associates, Inc. (2000) Upper Schuylkill river tributaries assessment report

Langmuir D (1997) Aqueous environmental geochemistry. PrenticeHall, New Jersey, 600 pp

McKenzie RM (1980) The adsorption of lead and other heavy metals on oxides of manganese and iron. Aust J Soil Res 18:61-73

Meador MR, Cuffney TF, Gurtz ME (1993) Methods for sampling fish communities as part of the National Water-Quality Assessment Program. US Geol Surv Open-File Rep 93-104, 40 pp

Nordstrom DK (1977) Thermochemical redox equilibria of Zobell's solution. Geochim Cosmochim Acta 41:1835-1841

Parkhurst DL, Appelo CAJ (1999) User's guide to PHREEQC (Version 2) - a computer program for speciation, batch-reaction, one-dimensional transport, and inverse geochemical calculations. US Geol Surv Wat Resour Inv Rep 99-4259, 312 p 
(ftp://brrcrftp.cr.usgs.gov/geochem/pc/phreeqc/phreeqci-2.12.5669.exe)

Pennsylvania Department of Environmental Protection (2003) Watershed Restoration Action Strategy (WRAS) Subbasin 06A Upper Schuylkill River Watershed Schuylkill, Carbon, and Berks Counties, PA. Pennsylvania Dept of Environmental Protection, Harrisburg, 16 pp (http://www.dep.state.pa.us/dep/ deputate/watermgt/wc/Subjects/Nonpointsourcepollution/ Initiatives/Wraslist.htm)

Pennsylvania Department of Environmental Protection (2004) 2004 Integrated list of all waters. Pennsylvania Dept of Environmental Protection, Harrisburg, 1807 pp (http://www.dep.state.pa.us/dep/ deputate/watermgt/wqp/wqstandards/303d-Report.htm)

Rantz SE, and others (1982a) Measurement and computation of streamflow-1. Measurement of stage and discharge. US Geol Surv Wat Sup Pap 2175, 1: 284 pp

Rantz SE, and others (1982b) Measurement and computation of streamflow-2. Computation of discharge. US Geol Surv Wat Sup Pap 2175, 2: 631 pp

Rose AW, Cravotta CA, III (1998) Geochemistry of coal-mine drainage. In: Brady KBC, Smith MW, Schueck JH (eds), The prediction and prevention of acid drainage from surface coal mines in Pennsylvania. Pennsylvania Dept of Environmental Protection, Harrisburg, 5600-BK-DEP2256, p 1.1-1.22

Singer PC, Stumm W (1970) Acidic mine drainage-the ratedetermining step. Science 167:1121-1123

Skousen JG, Rose AW, Geidel G, Foreman J, Evans R, Hellier W, and others (1998) Handbook of technologies for avoidance and remediation of acid mine drainage. National Mine Land Reclamation Center, Morgantown, $131 \mathrm{pp}$

Stumm W, Lee GF (1961) Oxygenation of ferrous iron. Indust Eng Chem 53:143-146

Stumm W, Morgan JJ (1996) Aquatic chemistry-chemical equilibria and rates in natural waters, 3rd edn. Wiley-Interscience, New York, $1022 \mathrm{pp}$

Stumm W, Sulzberger B (1992) The cycling of iron in natural environments - considerations based on laboratory studies of heterogeneous redox processes. Geochim Cosmochim Acta 56:3233-3257

Tamura H, Goto K, Nagayama M (1976) The effect of ferric hydroxide in the oxygenation of ferrous ions in neutral solutions. Corrosion Scie 16:197-207

Tarutis WJ Jr, Stark LR, Williams FM (1999) Sizing and performance estimation of coal mine drainage wetlands. Ecol Eng 12:353-372

Tewalt SJ, Sato M, Dulong FT, Neuzil SG, Kolker A, Dennen KO (2005) Use of ozone to remediate manganese from coal mine drainage waters. In: Proceedings of National Meeting of the American Soc of Mining and Reclamation, pp 1166-1176

U.S. Environmental Protection Agency (2002) National recommended water quality criteria-2002. US Environmental Protection Agency, EPA 822-R-02-047, 33 pp
U.S. Environmental Protection Agency (2006) Areas impacted by acidification-Acid mine drainage and acid deposition remain significant problems in region III. US Environmental Protection Agency, 1 p (accessed May 15, 2006, on the World Wide Web at http://www.epa.gov/Region3/acidification/r3_acidifcation.htm)

U.S. Geological Survey (1997 to present) National field manual for the collection of water-quality data. US Geol Surv Tech Wat Res Inv, 9: A1-A9, variously paged (http://pubs.water.usgs.gov/ twri9A)

U.S. Office of Surface Mining Reclamation and Enforcement (2002) AMDTreat 3.1. US Office Surface Mining Reclamation and Enforcement, Washington, DC, (accessed June 15, 2003 at http://amd.osmre.gov)

Watzlaf GR, Schroeder KT, Kairies CL (2001) Modeling of iron oxidation in a passive treatment system. In: Proceedings of 2001 National Meeting of the American Soc for Surface Mining and Reclamation 2, pp 626-638

Watzlaf GR, Schroeder KT, Kleinmann RLP, Kairies CL, Nairn RW (2004) The passive treatment of coal mine drainage. DOE/ NETL-2004/1202 (accessed May 15, 2006 at http://www.netl. doe.gov/technologies/coalpower/ewr/water/pdfs/Passive $\% 20$ Treatment.pdf), US Dept of Energy

Way JH (1999) Appalachian Mountain section of the Ridge and Valley province. In: Schultz CH (ed) The Geology of Pennsylvania. Pa Geol Surv, 4th series, Special Publ 1, pp 352-361

Webster JG, Swedlund PJ, Webster KS (1998) Trace metal adsorption onto an acid mine drainage iron(III) oxy hydroxy sulfate. Environ Sci Tech 32:1361-1368

Williams DJ, Bigham JM, Cravotta CA III, Traina SJ, Anderson JE, Lyon $\mathrm{G}$ (2002) Assessing mine drainage $\mathrm{pH}$ from the color and spectral reflectance of chemical precipitates. Appl Geochem 17:1273-1286

Williamson MA, Kirby CS, Rimstidt JD (1992) The kinetics of iron oxidation in acid mine drainage (abs). Program and Abstr, V. M. Goldschmidt Conf, University Park. The Geochemical Soc, p A-121

Winland RL, Traina SJ, Bigham JM (1991) Chemical composition of ochreous precipitates from Ohio coal mine drainage. J Environ Qual 20:452-460

Wood CR (1996) Water quality of large discharges from mines in the anthracite region of eastern Pennsylvania. US Geol Surv Wat Resour Inv Rep 95-4243, 69 pp

Wood GH Jr, Kehn TM, Eggleston JR (1986) Deposition and structural history of the Pennsylvania Anthracite region. In Lyons PC, Rice CL (eds) Paleoenvironmental and tectonic controls in coal-forming basins of the United States. Geological Soc of America Special Paper 210, pp 31-47

Wood WW (1976) Guidelines for the collection and field analysis of ground-water samples for selected unstable constituents. US Geol Surv Tech Wat Res Inv 1: D2, US Geol Surv, 24 pp 


\section{Appendix A:}

PHREEQC model of iron oxidation adapted from Example 9 of Parkhurst and Appelo (1999)

TITLE Kinetically controlled exsolution of carbon dioxide

coupled with oxidation of ferrous iron. Decoupled valence states of iron. SOLUTION_MASTER_SPECIES

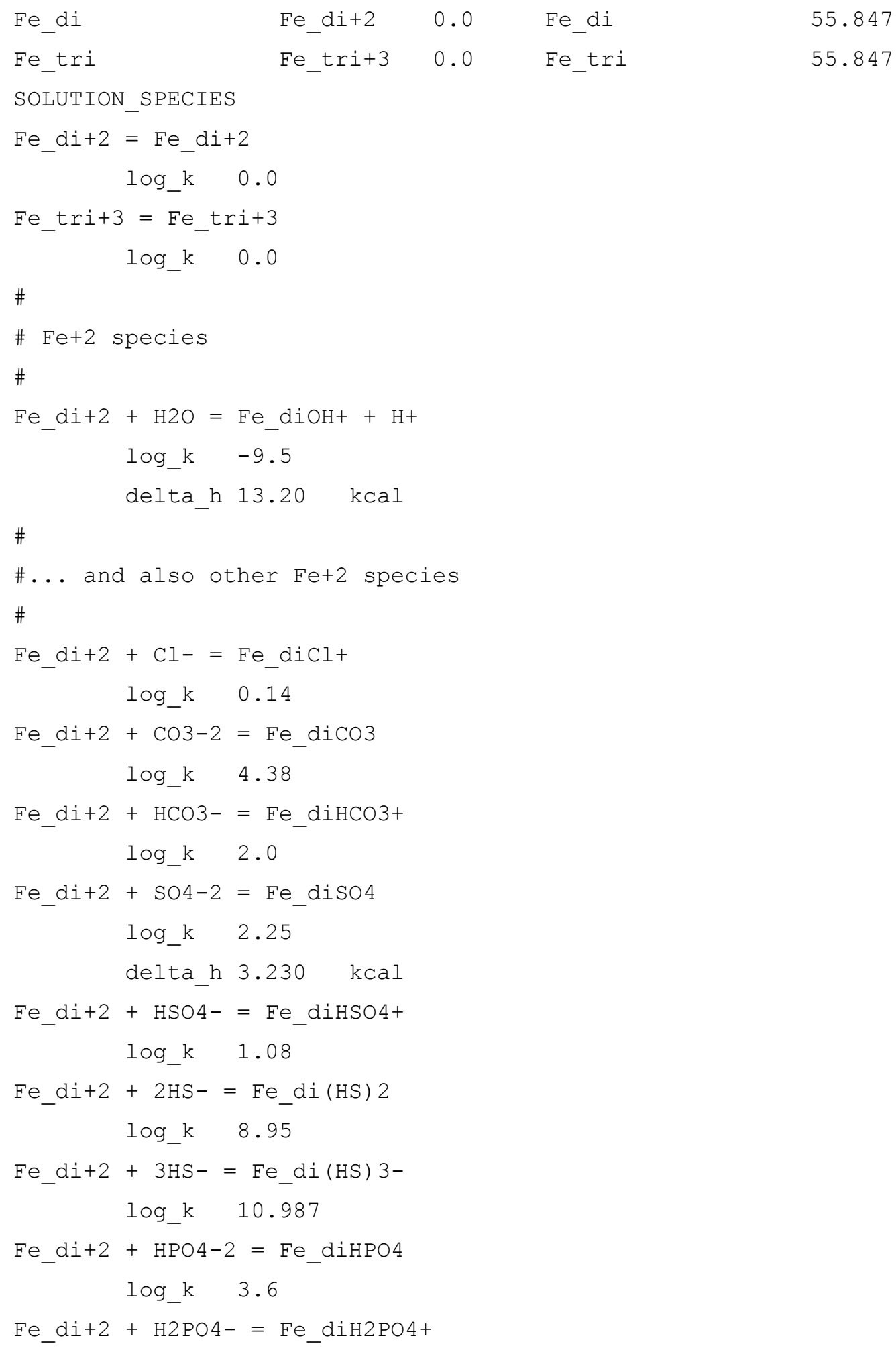




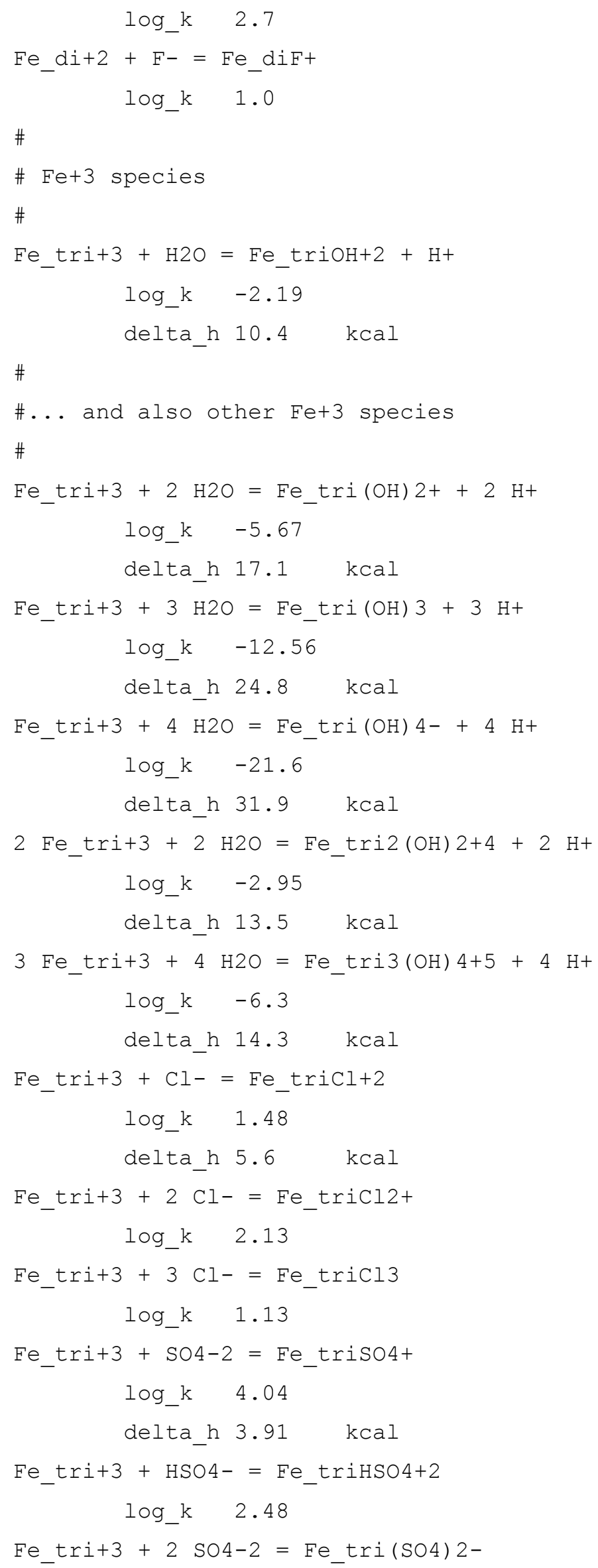




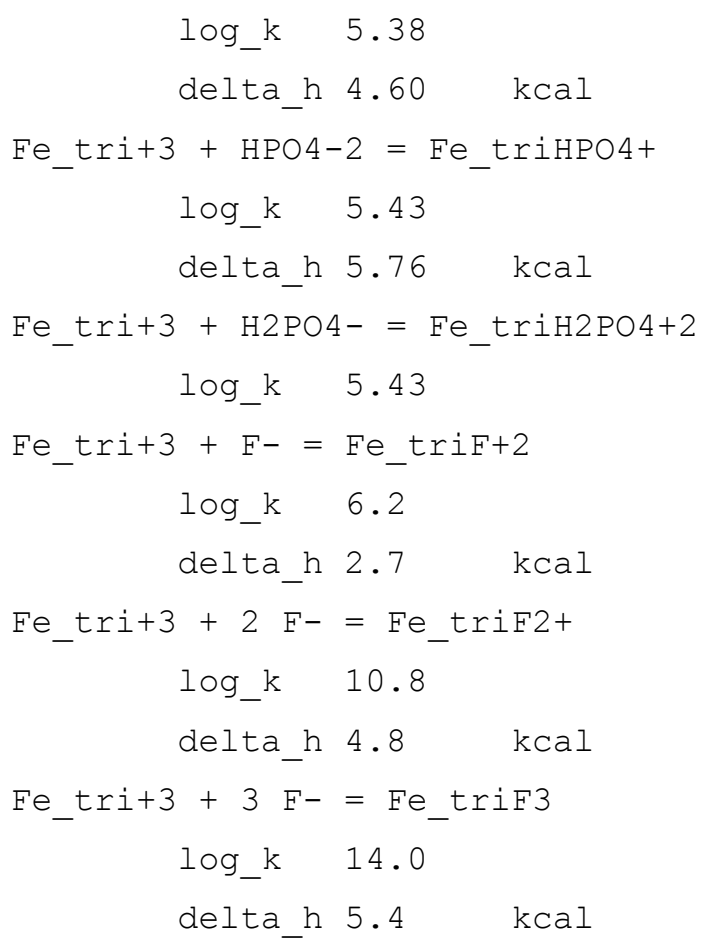

Goethite

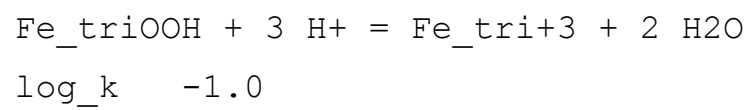

$\mathrm{Fe}(\mathrm{OH}) 3(\mathrm{a})$

$$
\begin{aligned}
& \text { Fe_tri }(\mathrm{OH}) 3+3 \mathrm{H}+=\mathrm{Fe} \text { tri+3 }+3 \mathrm{H} 2 \mathrm{O} \\
& \text { log_k } 4.891
\end{aligned}
$$

$02(g)$

$$
\begin{array}{lc}
02=02 & \\
\text { log_k } & -2.960 \\
\text { delta_h }-1.844 \mathrm{kcal}
\end{array}
$$

$\mathrm{CO} 2(\mathrm{~g})$

$$
\begin{array}{ll}
\mathrm{CO} 2=\mathrm{CO} 2 & \\
\text { log_k } & -1.468 \\
\text { delta_h }-4.776 \mathrm{kcal}
\end{array}
$$

END

\# Otto Discharge (December 3, 2001)

SOLUTION 1

$\begin{array}{ll}\text { temp } & 12.3 \\ \mathrm{pH} & 5.92 \\ \mathrm{pe} & 3.4 \\ \text { redox } & \mathrm{pe} \\ \text { units } & \mathrm{mg} / \mathrm{l}\end{array}$




$\begin{array}{ll}\text { density } & 1 \\ \text { Alkalinity } & 70 \\ \mathrm{Ca} & 42 \\ \mathrm{Cl} & 2.4 \\ \mathrm{Fe} \text { di } & 16000 \mathrm{ug} / \mathrm{I} \\ \mathrm{Mg} & 37 \\ \mathrm{Mn} & 2500 \mathrm{ug} / \mathrm{l} \\ \mathrm{S}(6) & 230 \mathrm{charge} \\ \mathrm{Na} & 11 \\ \mathrm{~K} & 1.2 \\ \text { Al } & 80 \mathrm{ug} / \mathrm{l} \\ \text { Zn } & 29 \mathrm{ug} / \mathrm{l} \\ \text { O(0) } & 0.21 \\ \text {-water } & 1 \mathrm{\#} \mathrm{kg}\end{array}$

\# Gas phase log (atm); mineral phase saturation index EQUILIBRIUM_PHASES 1

\begin{tabular}{|c|c|c|}
\hline \multirow{3}{*}{ \# } & $\mathrm{O} 2(\mathrm{~g})$ & -0.67 \\
\hline & $\mathrm{CO} 2(\mathrm{~g})$ & -3.5 \\
\hline & $\mathrm{Fe}(\mathrm{OH}) 3(\mathrm{a}) \quad 0.0$ & \\
\hline & Goethite 0.0 & \\
\hline
\end{tabular}

\section{RATES}

\# Exponential, asymptotic approach to steady-state $\mathrm{CO} 2$

$\mathrm{CO} 2(\mathrm{~g})$

-start

10 REM pCO2 data for batch oxidation experiment 12/3/01

$40 \mathrm{k}=-0.09061$

$50 \mathrm{dco} 2 \mathrm{dt}=2.303 * \mathrm{k} *(\mathrm{SI}(" \mathrm{CO} 2(\mathrm{~g}) ")--3.2) * \mathrm{MOL}(" \mathrm{CO} 2 ")$

60 moles $=$ dco $2 d t *$ TIME / 3600

100 save moles

-end

\# Exponential, homogeneous oxidation of ferrous iron

Fe_di_ox

-start

10 Fe_di $=$ TOT ("Fe_di")

20 if ( $\mathrm{Fe}$ _di $<=0)$ then goto 200

\#\# Stumm and Lee, 1961, SS1.pqi \#\# 


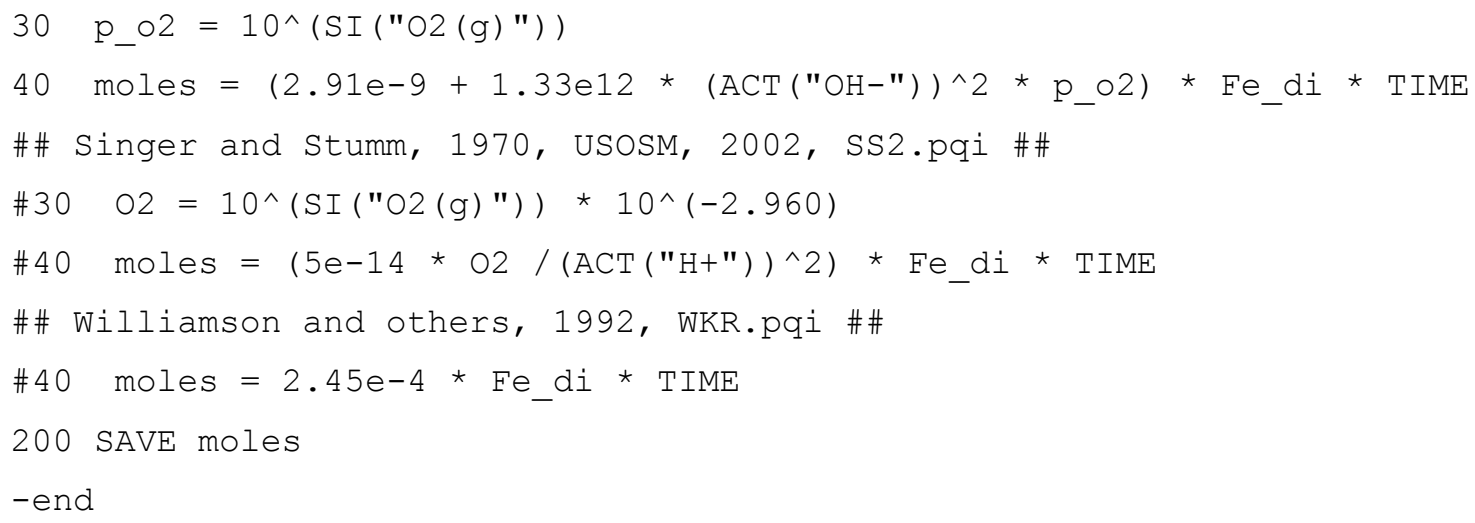


70 PUNCH SI("Goethite")

80 PUNCH SI ("Fe (OH) $3(a)$ ")

END 